\title{
Astronomical observations in the Inca Temple of Coricancha (Cusco)? A critical review of the hypothesis
}

\author{
Mariusz Ziółkowski \\ e-mail:mziolkowski@uw.edu.pl \\ Centre for Precolumbian Studies, University of Warsaw \\ Jacek Kościuk \\ e-mail: jacek.kosciuk@pwr.edu.pl
}

Faculty of Architecture, Wroclaw University of Science and Technology

\begin{abstract}
Coricancha (Qurikancha, Qorikancha) was the most important temple in Cuzco, the capital of Tawantinsuyu, the Inca Empire. The Spanish Conquistadores had the opportunity to see her, and her legendary richness, in November 1533, after entering Cuzco. Coricancha was the place to worship the most sacred effigies of the Inca cult, including the figure of the Sun, called Punchao. From this early period, there are also references, unfortunately not very precise, related to a specific orientation of some elements of the temple providing reflection of the rising (or setting) sun on the aforementioned figure of Punchao. Based on these sources, and the analysis of the remains of the original Inca Coricancha, a number of hypotheses regarding the possible astronomical function of this temple were formulated. Of particular importance was the hypothesis of Zuidema and Aveni, according to which astronomical observations at Coricancha constituted the structural skeleton of a specific Inca calendar cycle of 328 days. This article presents a critical analysis of this hypothesis, based on long-term research and measurements carried out in the Coricancha by the authors of the text.
\end{abstract}

Keywords: Incas, Coricancha, Punchao, astronomic orientation, Inca calendar, metrology

\section{Introduction}

Since the beginning of the $20^{\text {th }}$ century, several academics have researched the possible astronomical functions of some of Cusco's constructions and of those in the surrounding areas. Nevertheless, the authors, whose contributions were of great importance and gained recognition (at least in their time) were the Germans Roberto Lehmann-Nitsche and Rolf Müller ${ }^{1}$. But in the 70 s, it was Anthony F. Aveni and R. T. Zuidema who contributed in a more significant way to the development of studies in this field, presenting a series of proposals about the geographical location of some of these places designed to make astronomical observations that have been mentioned in historical sources. The structures to which these two scholars have paid special attention were the sucancas of the Picchu hill, which could be seen, according to an anonymous chronicler, on the horizon 
west of Cusco; and the Coricancha temple. Another topic that has been studied by these authors is the possible astronomic role of some of the ceques (Zuidema 1977;1981; Aveni 1981).

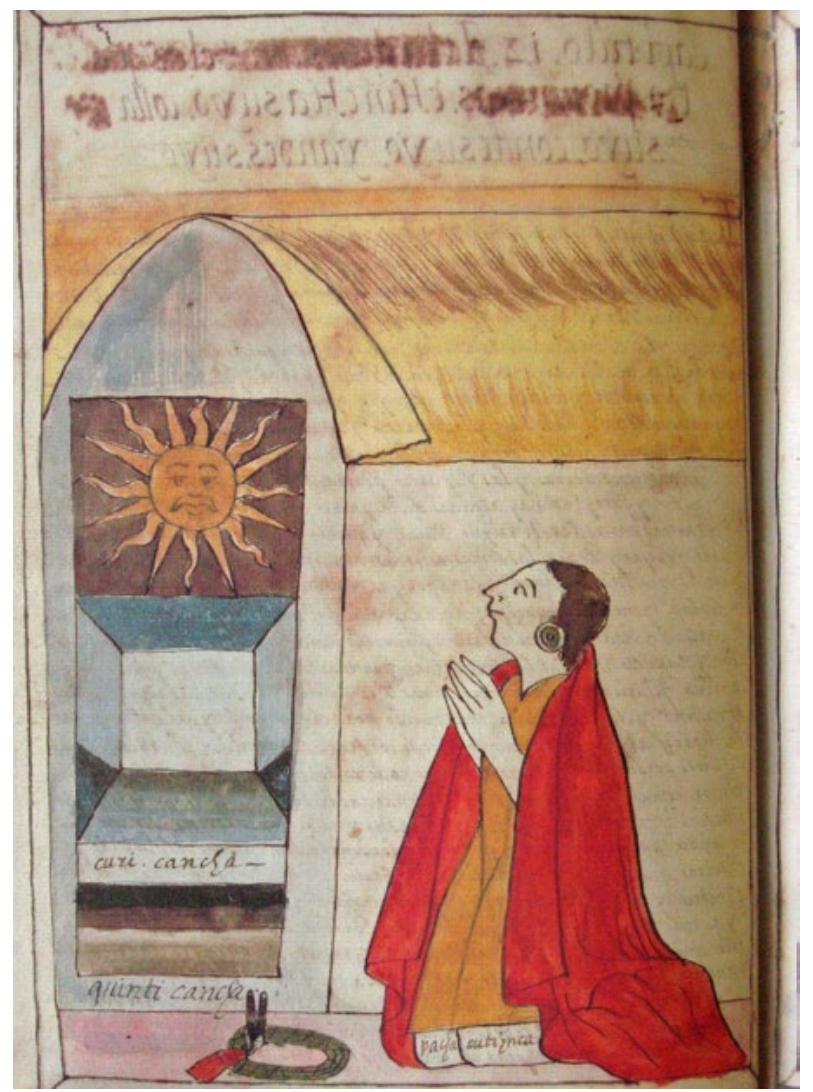

Fig. 1. The Inka worshiping the effigy of the Sun in the temple of Coricancha. Martín de Murúa, Galvin Manuscript (courtesy of Juan Ossio).

Inka adorujący wizerunek Słońca w świątyni Coricancha. Martín de Murúa, Galvin Manuscript (dzięki uprzejmości Juan Ossio).

Zuidema postulated that the Incas were particularly interested in observing eight critical moments of the 'route', or the apparently annual displacement, of the Sun:

1. The solstices: on December $21^{\text {st }}$ and June $21^{\text {st }}$.

2. The equinoxes: on March $\mathbf{2} 1^{\text {st }}$ and September $23^{\text {rd }}$.

3. The passages of the Sun through the zenith of Cusco, on October $\mathbf{3 0}{ }^{\text {th }}$, and February $\mathbf{1 3}^{\text {th }}$.

4. The so-called 'passage of the Sun by the anti-zenith' or nadir of Cusco - on August $\mathbf{1 8}^{\text {th }}$ and April $\mathbf{2 3}^{\text {rd }}$. Anti-zenith, or nadir, corresponds to the point of the celestial sphere that is directly opposite the zenith and vertically downward from the observer. Of course, it is not possible to observe directly the transit of the Sun by the anti-zenith, but this moment, or rather the day, could be determined in the following way: observing the point on the horizon in which the sun sets on the day of its transit through the local zenith, and reversing this direction by 180 degrees, we get the sun's rise point on the day of its passage through anti-zenith (nadir). In the analogic way, we can fix the sun's sunset point on that day reversing the sun's sunrise direction on the day of its Zenithal transit (Fig. 2).

5. To this, it should be added that the observation of sunrise when the sun's rays cut through the axis of the Coricancha's main corridor would occur on two dates: May $\mathbf{2 5}^{\text {th }}$ and July $\mathbf{1 8 ^ { \text { th } }}$; according to Zuidema, these two dates were the key for organising the Incas' calendar cycle. (Zuidema 1981; 2010).

2 It is noteworthy that over the years and the progress of the research, these authors, and Tom Zuidema in particular, modified their original hypotheses at various points, as revealed by the comparative reading of the first and the last works mentioned (Zuidema, 1982, 2008, 2011, 2014).

3 Dates are according to the Gregorian calendar. The dates according to the Julian calendar were in use by the Spanish administration (and the chroniclers as well) in Peru until 1584. They are earlier for 10 days, so, for example, the December solstice fell on the 10/11 of the month, etc. 


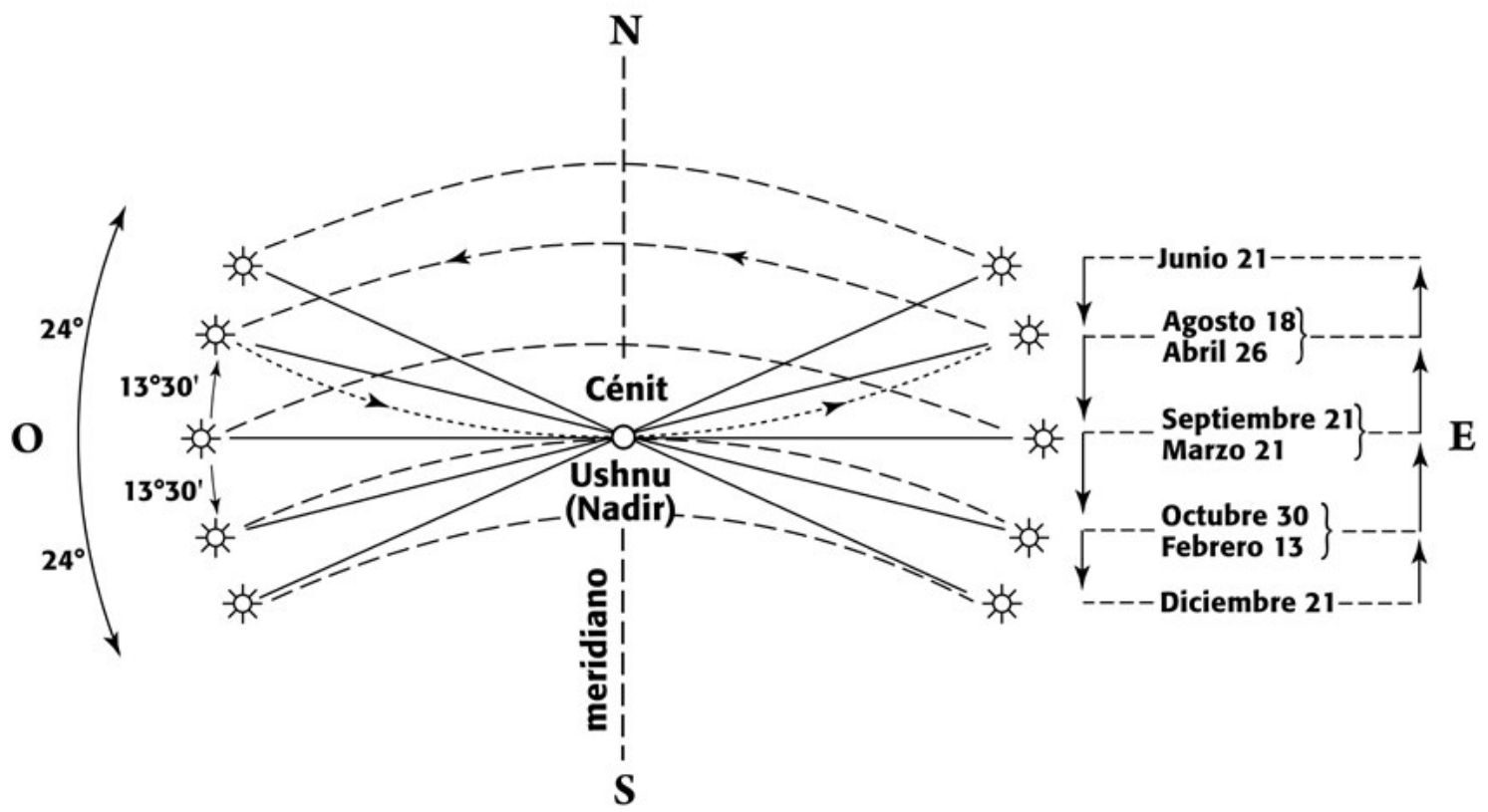

Fig. 2. The eight critical moments of the "route" or apparent annual displacement of the Sun, observed from the latitude of Cusco (Zuidema 2010).

Osiem tzw. "krytycznych" momentów w rocznej wędrówce Słońca po horyzoncie, obserwowanych na szerokości geograficznej Cusco (Zuidema, 2010).

Zuidema and Aveni's works served as reference points for the investigations addressed later by other researchers, among which we can highlight Brian Bauer and David Dearborn. In 1995, both the authors published a valuable study entitled Astronomy and Empire in the Ancient Andes, in which they summarised a large part of what was known by then on the astronomical knowledge reached by the Incas (Bauer and Dearborn 1995). They conducted field prospections around Cusco, as well as studies of the historical sources, with the purpose of analysing, in detail, the hypotheses formulated by Aveni and Zuidema. In several points, the conclusions reached by Bauer and Dearborn differ significantly from the postulates of Aveni and Zuidema. In this study, we will follow the course drawn by Bauer and Dearborn, tackling in detail the topic of possible astronomical observations carried out in the main temple of Coricancha in Cusco, because of their particular importance for the structure and the functioning of the calendar-ceremonial system of the Inca Empire.

\section{The Coricancha (Qurikancha)}

This name is attributed to the main temple of Inka cult, located in the heart of Cusco, on a small hill at the junction of two streams (now covered). Its exact geographical coordinates are $13^{\circ} 31^{\prime} 12.3^{\prime \prime} \mathrm{S}, 71^{\circ} 58^{\prime} 30.9^{\prime \prime} \mathrm{W}$, elevation $3391 \mathrm{~m}$ asl (Google Earth).

Before moving to the main topic of this article, that is, to the discussion about the possible astronomical functions of Coricancha, we must ask a question of particular importance, namely: to what extent the compound, as we see it today, corresponds to the form that Coricancha had, for example in $1530 \mathrm{AD}$, it means before the arrival of the Spaniards?

Without going into the details of this profusely debated subject ${ }^{4}$, let us remember some basic facts. The first historical news about this temple comes from 1533, in the context of the richness of its decoration in gold (in 
particular, the frieze of this metal), which was looted by the Spaniards ${ }^{5}$. In spite of this, eyewitnesses underline that even in mid-1537 the whole temple was apparently structurally intact, so it could, for example, serve as a prison for the brothers Pizarro captured by Diego de Almagro 'El Viejo' and his followers ${ }^{6}$.

The first somewhat detailed description of Coricancha dates from the early 1540s, from the chronicle of Pedro Cieza de León is as follows:

This temple had in circuit more than four hundred steps, all surrounded by a strong wall, all the building of excellent stonework with perfectly processed stones, precisely placed and settled, some of the stones were very large and impressive; they had no mortar of earth or lime, but only the bitumen with which they usually make their buildings, and these stones are so well carved, that it does not seem to be a seam or a joint between them. (...) The stones seemed to me to be something black and coarse and very excellent. There were many doors, and the facades very well carved; in the middle of the wall, a gold ribbon two hands wide and four fingers high. The facades and doors were covered with plates of this metal.

Further in were four houses, not very large, carved in this manner, and the inside and outside walls were plated with gold, as was the carpentry, too, and the roof was made with straw that served as tiles. There were two seats in that wall, which the sun illuminated on rising, and the stones [of the seats] were spottily perforated and in the holes, many precious stones and emeralds were embedded. In these seats [only] the kings sat, and if someone other did, he was punished with death. ${ }^{7}$

There, for the first time, an information appeared about a type of solar observations that had been realized in the temple for ceremonial events: '... two seats in that wall, which the sun illuminated on rising ....'

Bartolomé de las Casas, apparently based on the information of Cieza de León, presents a slightly different interpretation of this device:

In a part of the temple there was a piece as an oratory, to the part of the East where the Sun rises, with a large wall, from which came a roof six feet wide, and on the wall there was a niche where the image of the Sun was put, in the mornings, when the sun is rising. (...) and after noon they passed the image to the opposite part, in another lace, so the setting Sun faces the effigy. ${ }^{8}$

5 The earliest reference on the "houses of the Sun" (the name Coricancha, or "the Golden Enclosure", was given to this compound later) and their fabulous treasures came from Cristóbal de Mena relation, published in Seville in 1534 (Mena). Compare also the testimonies of others Conquistadores: Juan Ruiz de Arce, Relación de servicios, 1933 [1545], pp. 371-372; Pedro Sancho (1917 [1533], chap. XIV, pp. 185), Pedro Pizarro, ( [1571], chap. 15)

6 ... y luego llevaron a Hernando Pizarro y a Gonzalo Pizarro a las casas del Sol por ser aposento muy fuerte poniendo con ellos un Capitan con treinta hombres para que los guardasen... ["... and then they took Hernando Pizarro and Gonzalo Pizarro to the houses of the Sun, because it was a very strong compound, putting with them a Captain with thirty men to guard them...] (Anónimo, 1539: 114). Translation into English by the Authors.

7 Tenia este templo en circuito más de cuatrocientos pasos, todo cercado de una muralla fuerte, labrado todo el edificio de cantería muy excelente de fina piedra muy bien puesta y asentada, y algunas piedras eran muy grandes y soperbias; no tenían mezcla de tierra ni cal, sino con el betún que ellos suelen hazer sus edificios, y están tan bien labradas estas piedras, que no se le parece mezcla ni juntura ninguna. (...)

La piedra me pareció ser algo negra y tosca y excelentísima. Habia muchas puertas, y las portadas muy bien labradas; á media pared, una cinta de oro de dos palmos de ancho y cuatro dedos de altor. Las portadas y puertas estaban chapadas con planchas de este metal.

Más adentro estaban cuatro casas no muy grandes labradas desta manera, y las paredes de dentro y de fuera chapadas de oro, y lo mesmo el enmaderamiento, y la cobertura era paja que servia por teja. Habia dos escaños en aquella pared, en los cuales daba el sol en saliendo, y estaban las piedras sotilmente horadadas y puestas en los agujeros muchas piedras preciosas yesmeraldas. En estos escaños se sentaban los reyes, y si otro lo hacia, tenia pena de muerte. (Cieza, II p., Cap. XXVII: 105-107). Translation into English by the Authors.

8 A una parte del templo había cierta pieza como oratorio, hacía la parte del Oriente donde nasce el Sol, con una muralla grande, de aquélla salía un terrado de anchura de seis pies, y en la pared había un encaje donde se ponía la imagen grande del Sol /.../. Esta ponían, cuando el Sol salía en aquel encaje, las mañanas, que le diese de cara el sol, y después de mediodía pasaban la imagen a la contraria parte, en otro encaje para que también le diese, cuandoo se iba poner, el sol de cara. /Las Casas, 1958, cap. CXXXI, pp. 451-452. Translation into English by the Authors. 
We will return to this topic in the final part of this study.

Going back to the theme of changes in the structure of the temple, we note that by 1570 AD it had undergone major changes due to its adaptation of the needs of the Convent of Santo Domingo that was installed in this precise place ${ }^{9}$. Until now, the convent has had its headquarters there, which has necessarily been the cause of several alternations and remodelling of the original Inca structures throughout the Colonial and Republican Period.
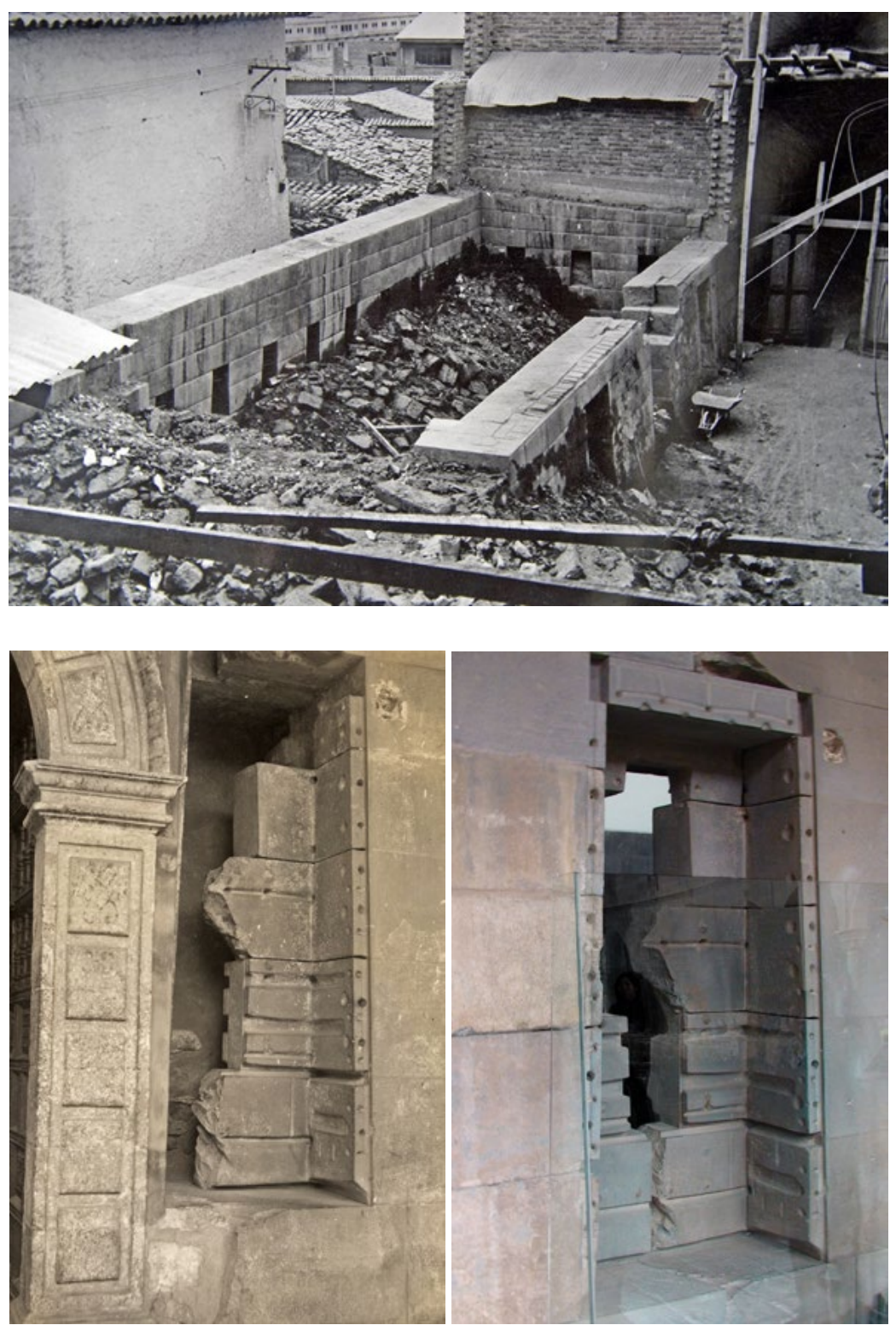

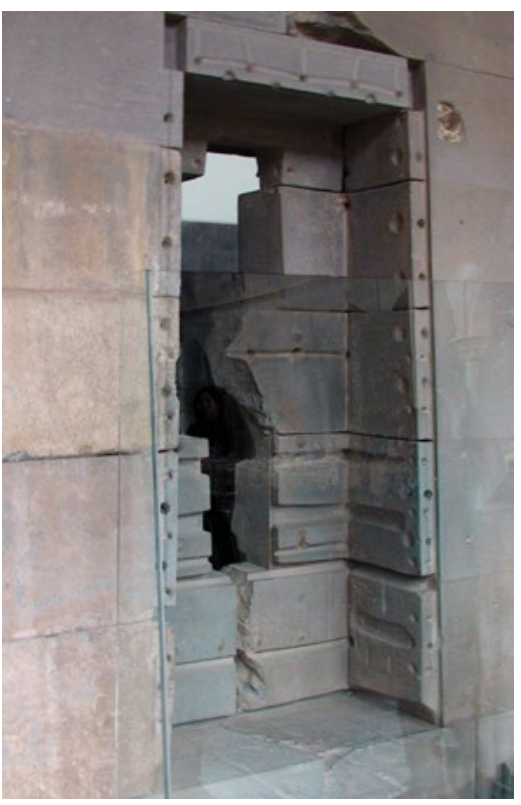

Fig. 3. Coricancha after the disastrous earthquake of 1950.Photo from the Oscar Ladrón de Guevara private archive (courtesy of César Ladrón de Guevarra).

Coricancha po trzęsieniu ziemi w 1950 roku. Zdjęcie z prywatnego archiwum Oscar Ladrón de Guevara (dzięki uprzejmości César Ladrón de Guevarra)

Fig. 4. Coricancha. The niche in the facade of the "Room of the Stars". Left: situation by 1942. (Photo from the John $\mathrm{H}$. Rowe private archive courtesy Patricia J. Lyon). Right: the present day view after reconstruction by Oscar Ladrón de Guevara. (Photo Jacek Kościuk).

Coricancha. Nisza na elewacji tzw. "Sali Gwiazd". Po lewej: stan z ok. 1942 roku (zdjęcie z prywatnego archiwum John H. Rowe dzięki uprzejmości Patricii J. Lyon). Po prawej: stan współczesny po rekonstrukcji przez Oscara Ladrón de Guevara (zdjęcie Jacek Kościuk)

Let us also point out two important natural events that have altered the structure of Coricancha: the disastrous earthquakes of $1650 \mathrm{AD}$ and $1950 \mathrm{AD}$ (Fig. 3). The last one gave an occasion to a project of a general reconstruction of the whole compound, in charge of the architect Oscar Ladrón de Guevara Aviles. In fact, several

9 Compare the short description by Fray Reginaldo de Lizárraga (Lizárraga, 1605 [2002], pp. 170-171), a Dominican friar (1545-1615), born, in Spain who spent most of his life in America. His work 'Descripción breve de toda la tierra del Perú, Tucumán, Río de la Plata y Chile' finished in 1605, was not published until 1908. The description of Coricancha in it probably comes from the 1570, when Lizárraga visited several times Cuzco. 
Inca architectural elements, which were hidden by the colonial constructions, have been uncovered. At the same time, a partial anastylosis of the Inca structures reconstructed several missing parts of the original walls.

To evaluate the importance of these interventions, just compare the photos of the famous niche in the east wall of the so called 'Enclosure of the Stars' in 1944 with its current appearance (Fig. 4), after the aforementioned restoration works.

Anyway, according to both archaeological and historical evidence, it seems that the external appearance of this complex would not be much different from other Cusco palaces: a complex consisting of a number of sheds or rectangular buildings, covered with straw, located around a central patio. It was surrounded by a polished stone wall. The number of structures located inside the enclosure is still to be established. According to the current research, it appears that there were all together nine buildings, and of these, all, but one, were connected directly with the central patio (Fig.18) ${ }^{10}$.

The temple had a rectangular form, except for the western enclosure wall, which was curved, and higher than the others, because it rested on the side of a hill, giving it a balcony shape (Fig. 5 and 18).

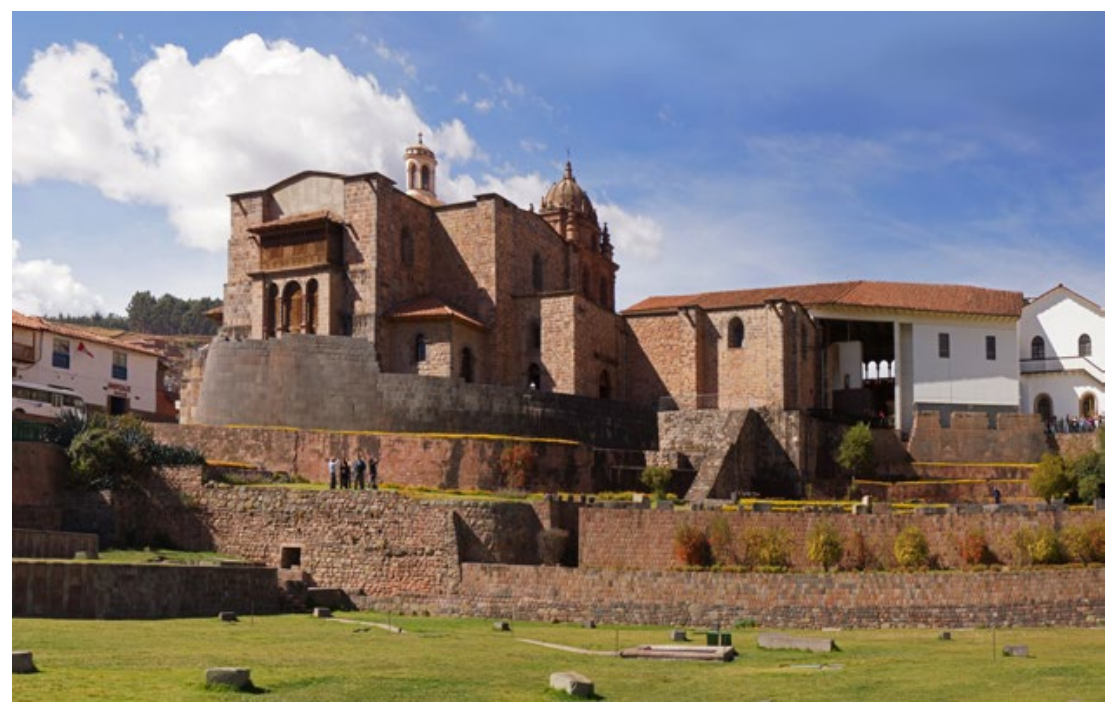

Fig. 5. The curved wall of the 'balcony' of the Coricancha (photo Jacek Kościuk).

Fragment inkaskich murów Coricancha - zakrzywiona ściana tzw. „balkonu” (zdjecie Jacek Kościuk).

In summary, the current form of Coricancha has been profoundly altered since the Inca times. Although the general layout and part of the walls of the enclosures as well as the famous curvilinear balcony are undoubtedly authentic, in other parts we are confronted with the presence of restoration effects and contemporary anastylosis. Therefore, any study of archaeo-astronomic character must be carried out with extreme caution and, preferably, based on undoubtedly pre-Hispanic vestiges.

Regarding the historical references about the disposition of certain elements within the Coricancha, which could be associated with astronomical observations of some kind, the only existing information is that about the '... two seats on that wall, which the sun illuminated on rising...'.

\section{The hypothesis on the astronomical-calendric function of the Coricancha (Qurikancha)}

The hypothetical astronomical function of Coricancha and the result of studies by different authors, particularly those mentioned in the introduction, have been summarized as follows by lan Farrington: 
It is clear that certain solar observations must have been made from Qorikancha, particularly of the sunrises and sunsets thought to be critical to the inkas, such as solstice, zenith, and anti-zenith. Various scholars have speculated about what was observed. For example, Zuidema (1982: 214) argued that both the June solstice sunrise and the heliacal rise of Pleiades could have been viewed above the alcove wall from the doorway between $R-3$ and R-4. The December solstice sunrise could have been observed from the southern terrace. In terms of sunsets, Bauer and Dearborn (1995: 77-78) provided evidence that the December solstice sunset behind Killke mountain could have been viewed from the corridor between $R-3$ and $R-4$ as well as from Intipampa (Farrington 2013, p.).

In their first studies, Zuidema and Aveni postulated a special role of the so-called ceques or 41 symbolic lines that came from the Coricancha and its vicinity. They considered these perfectly straight lines, visualized on the ground by successive sanctuaries or huacas (Fig. 6).

Some of those lines were supposed to mark a specific orientation for astronomical observations at the horizon (Zuidema 1982b; 206) ${ }^{11}$. Aveni and Zuidema suggested that from the Coricancha, with the help of the ceques lines, several solar phenomena could be observed, possibly a sidereal one.

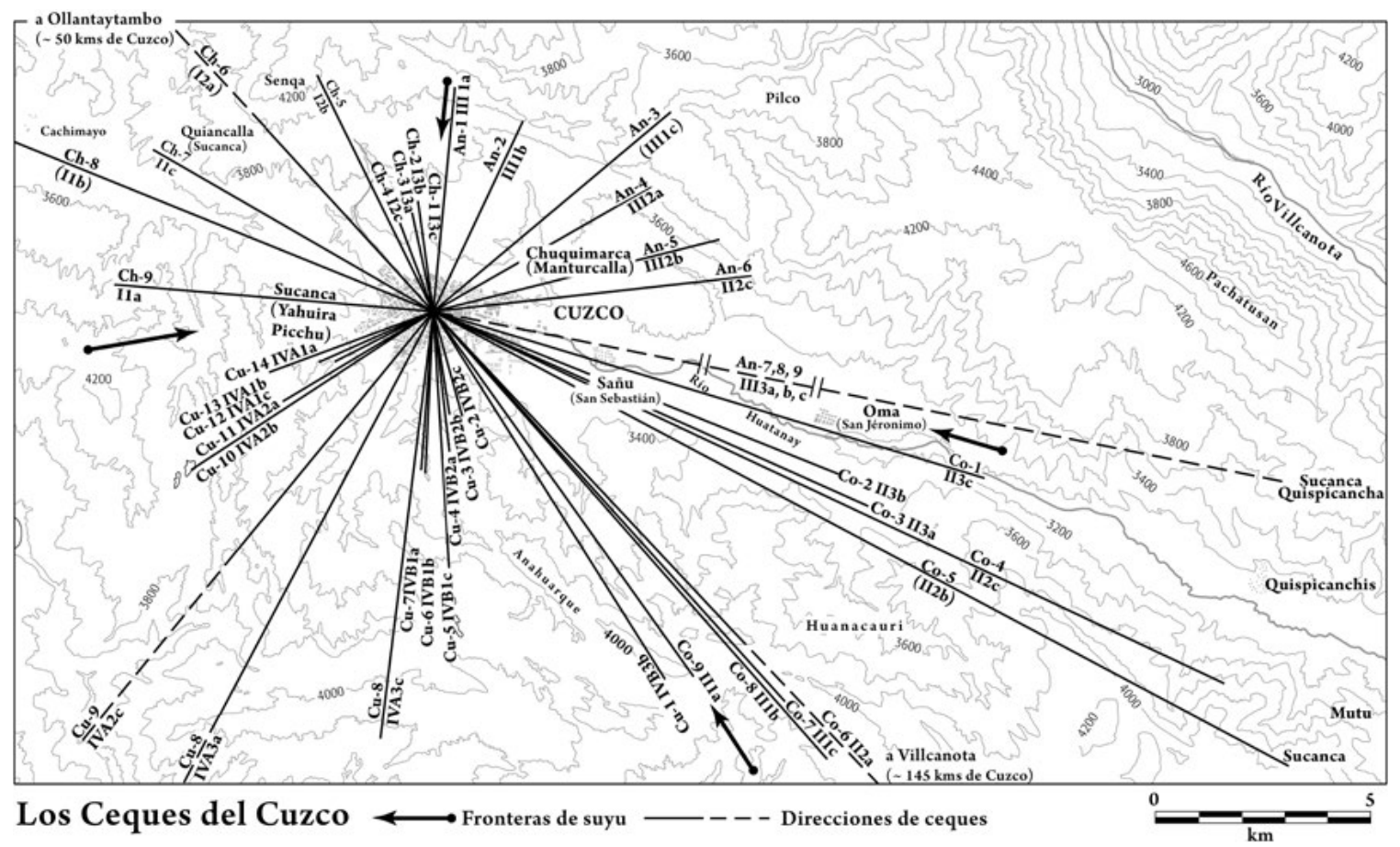

Fig. 6. The distribution of the 41 lines or ceques, according to R.T. Zuidema (Zuidema, 2010).

Rozkład 41 linii zwanych ceques, wg interpretacji R.T. Zuidemy (Zuidema, 2010).

We can summarize their hypotheses in a few points.

1. During the December solstice, the sunset could be seen from the Coricancha looking towards the sucanca located on the Chinchícalla hill (Cu-13:3): 'the third [huaca], Chinchicalla, was a big hill with two markers which, when reached by the Sun, meant it was time to sow' (Rowe, 1979:57).

2. According to Aveni and Zuidema, the east wall of the buildings on the terrace looks toward the azimuth angle $66^{\circ} 44^{\prime}$. The azimuth is measured on the horizon and it is the angle between the North cardinal 
point (origin) and the point established by the intersection of the heavenly body (in this case, the sun) with the line of the horizon. This angle is calculated clockwise. Therefore, the established point of $66^{\circ} 44^{\prime}$ on Cusco's horizon would be the place of the sunrise more or less around the $25^{\text {th }}$ of May Gregorian style (which would be the $15^{\text {th }}$ of May according to the Julian calendar in the $16^{\text {th }}$ century). This date would be of great importance in the Cusco's calendar according to the above-mentioned scholars ${ }^{12}$. There is, however, no proof of the existence of any sucanca located on this part of the eastern horizon of Cusco, but the corridor axis corresponds, more or less, to the direction of the Ceque An-5 (Zuidema; ceque III, 2b).

3. This last alignment would be the one in the direction of the heliacal rising of the Pleiades - that is, when they appear in the sky, after being invisible since May, one hour before sunrise - between the $6^{\text {th }}-9^{\text {th }}$ of June according to the Gregorian calendar ( $27^{\text {th }}-30^{\text {th }}$ May, Julian style).

According to Zuidema, this relation is reinforced by the roles and attributions of the Ceque An-5 and, especially, of one of its huacas: Susumarca $(A n-5: 8)^{13}$. We think that the first postulate, that the sunset was visible from Coricancha during the December solstice, is plausible because the sector of the horizon in which the sunset happens on the aforementioned date is undoubtedly visible from the temple, and it seems to match the location of one of the sucancas: [Cu-13:3] 'The third (huaca) Chinchicalla is a big hill, with two markers, that when reached by the Sun meant it was time to sow' (Rowe 1979). Nevertheless, even though Zuidema gave a very detailed debate and analysis of all the historical sources about this huaca (Zuidema 2011: 148ff.), we lack archaeological evidence about the precise location of these 'markers', as well as the distance between them.

At this point, it is essential to ask the following question: what kind of supposed astronomical observations postulate Zuidema and Aveni for Coricancha? It is obvious that the practical observation of celestial phenomena, requires some, even rudimentary, devices, such as a gnomon or properly planned and oriented buildings. It should also be noted that, when discussing devices used for tracking the movement of celestial bodies, two different categories of arrangements are considered:

Those, due to religious and ceremonial reasons, aimed at an approximate orientation towards the rising or setting of the sun (or another celestial body) at some important moment in its annual transition across the horizon. In these cases, precision of astronomical observation is not so important but rather creating a visual effect for the masses of the faithful gathered in spacious plazas in the main ceremonial centres (Aveni 1981; Ziółkowski 2015).

Those, which may be called 'precise astronomical instruments', were intended for the use by a few priest-astronomers, as mentioned in some sources (Sarmiento de Gamboa, Anónimo 1906: 151-152).

Recently, two such 'precise astronomical instruments' located within the perimeter of the Archaeological Park of Machu Picchu, namely Intimachay and the Mirador de Inkaraqay, were unveiled. (Dearborn, Schreiber and White 1987; Ziółkowski, Kościuk, Astete 2013; Astete, Ziółkowski, Kościuk 2018).

Looking at the evidence referred so far by Zuidema and Aveni, it is very difficult to decide which of the aforementioned categories they postulate for the case of Coricancha. We don't precisely know the place, inside of the Coricancha's perimeter, where such observations of the sun could have been made. With respect to this point, Zuidema tried to compare the historical data that were available with the position of the Incan structures inside the Coricancha. Taking this analysis as a basis, he proposed the hypothesis that a window might have 
existed in the curved side of the perimeter wall of the Coricancha, from where the sunset might have been visible during the winter solstice from a structure called Inticancha (Zuidema 2011:134ff.) ${ }^{14}$.

But, the same as in the case of the above-mentioned sukanka, these are assumptions, not evidence. In the absence of the latter, nothing specific can be said about the accuracy of such observations, or even about whether they were actually carried out.

\section{The alleged 'calendar skeleton' - the solar dates of the $25^{\text {th }}$ May and the $18^{\text {th }}$ July}

We think that the second theory by Aveni and Zuidema is much more interesting. The corridor between the two ceremonial buildings (together with their facades) pointed, from the western side of Coricancha's terrace, towards the sunrise on the $25^{\text {th }}$ May and $18^{\text {th }}$ July (Gregorian calendar). These dates (especially the first one) have been one of the key arguments from Zuidema to support his model of 'quipu-calendar', which would have had 328 nights/days represented by an equal number of huacas in the ceque system (Zuidema 1982; 2011; 131ff.; 2014: 859). The gap in days between the $25^{\text {th }}$ May and the $18^{\text {th }}$ July, determined by the successive appearances of the rising sun in the direction indicated by the aforementioned corridor was, according to Zuidema, an argument that supported the alleged ritual importance of a cycle of 55 nights/days, that equalled a 'double sidereal-lunar month' $(2 \times 27.3 \approx 55)$, a theoretical construction of great importance for his model of 'quipu-calendar' (Zuidema 2011: 131ff.).

\section{Critical analysis of Aveni and Zuidema's hypothesis}

The aforementioned assertions have, for years, been accepted at face value, without anybody making an effort to check in situ if the measurements made by Zuidema and Aveni in 1976 and 1980 were correct, and therefore, check the reliability of the explicative models made by these two scholars. Let us look more closely at the measurements made in Coricancha and one that constituted the foundation for these authors:

Our transit measurements reveal that the western wall is pointing to the horizon, towards an azimuth of $66^{\circ} 44^{\prime}$ (the average of the two measurements taken in 1976 and 1980) of $\pm 5^{\prime}$, and that the eastern wall is looking towards an azimuth of $248^{\circ} 13^{\prime}$ (both measurements from 1980), with the same margin of error. Therefore, the walls are anti-parallels by $1^{\circ} 29^{\prime}$. The eastern horizon is elevated $5^{\circ} 36^{\prime}$ above the real horizon. The sunrise during the June solstice of the year 1500 AD happened at $64^{\circ} 20^{\prime}$, or around 5 solar discs (27 days) to the left (North) of the alignment ${ }^{15}$.

These claims are illustrated with two figures to facilitate the demonstration that follows (Fig. 7 and 8). It is important to note that the scholars, apparently, did not make their own survey of this sector of Coricancha, but they took some plans that existed at the time for reference.

Taking into account the dates used for this study (1976 and 1980), and some details that were unknown before the earthquake of 1950, which excludes the plan by Rowe made in 1944, then they had the following options:

- the plan (a little bit schematic), published by Gasparini and Margolies in their classic 'Inca Architecture' (Gasparini and Margolies 1977),

14 Zuidema identifies it as "Inticancha", in the north-western part of the enclosure, based on different assumptions, in turn, influenced by some descriptions of the Coricancha (Zuidema, 2010: 145, ff.). But the only archaeological evidence in support of his argument is limited to a re-interpretation of a piece of information from Max Uhle's visit to the Coricancha in 1905. Zuidema himself summarizes the original information of the illustrious German archaeologist (prior to the re-interpretation) in the following way: '... Uhle reported that the wall he saw (which no one ever saw again) was a front wall approximately 12 meters long, with two doors and a niche in the middle of them. Uhle placed it just behind the north wall, which is an unlikely solution ...' (Zuidema 2010: 146).

15 Zuidema gives the following reference to these data, saying that they are: '... the astronomical measurements that Aveni and I took in 1976 and in 1980...'; '... I continue his analysis taken from his 1980 notes (reproduced here with his permission)...' (Zuidema 2010: 129). 
and, possibly, the plan published by Oscar Ladrón de Guevara in 1967 (Ladrón de Guevara 1967), but only as a reduced version and not the original in the scale of 1:100 (Fig. 9).

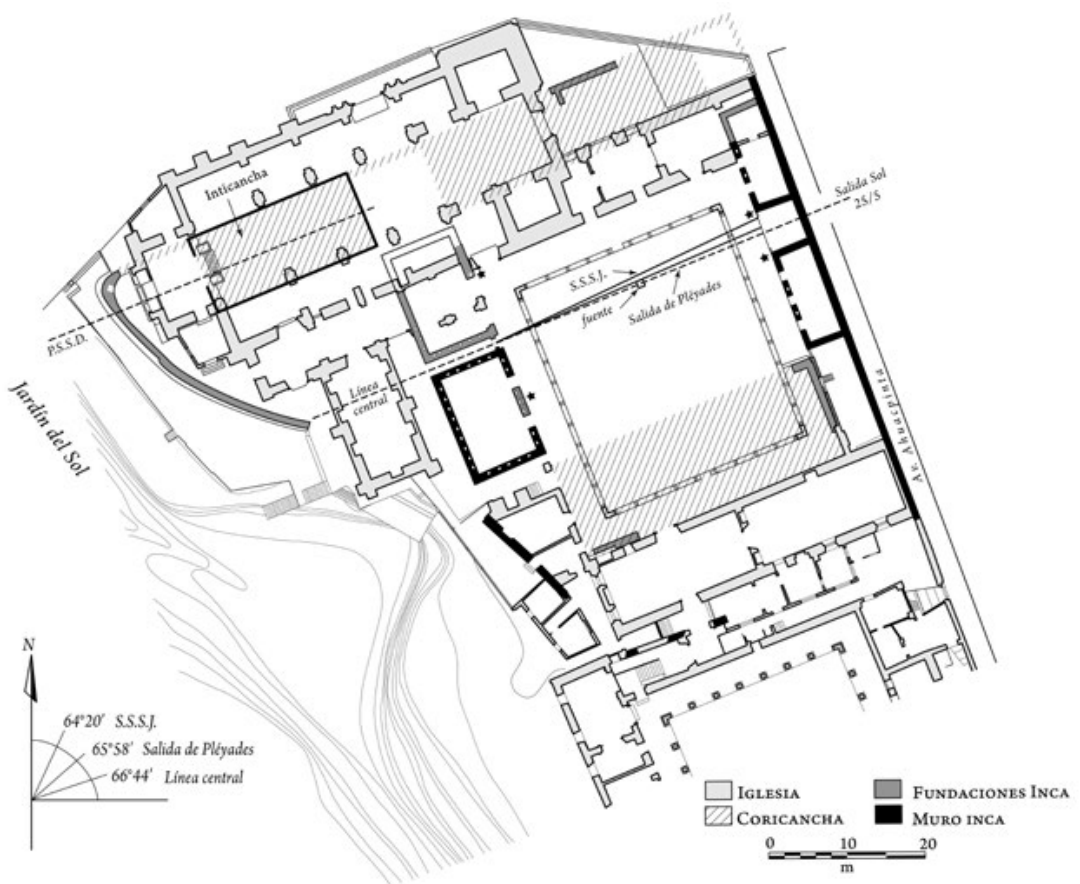

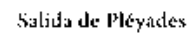

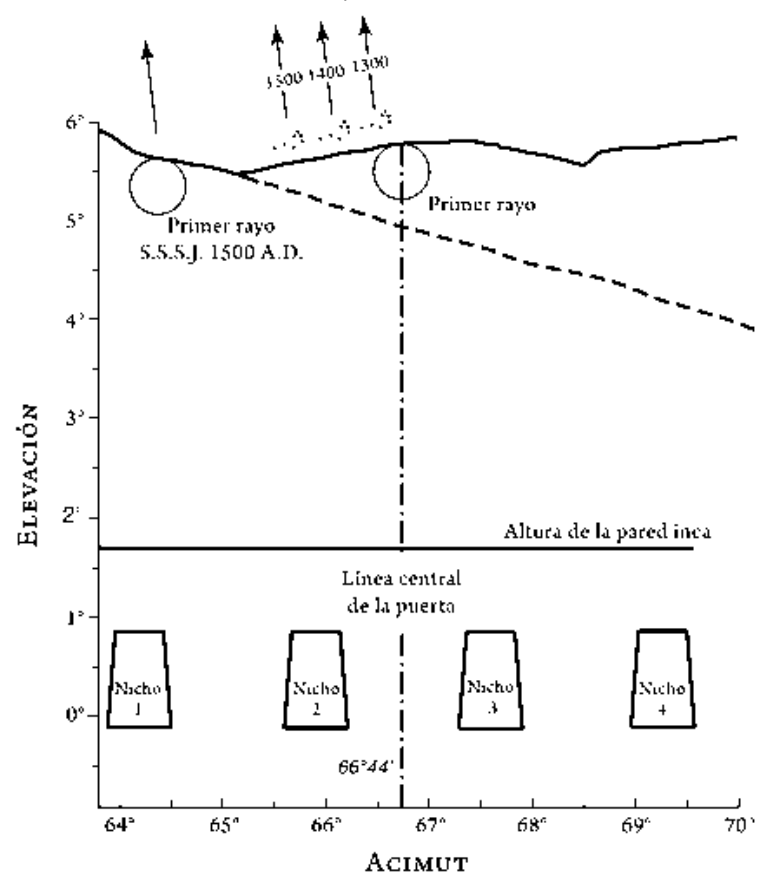

Fig. 7. The Coricancha and its astronomical alignments, according to the interpretation of A.F. Aveni and R.T. Zuidema The authors apparently used as a basis for their analysis a published plan (Gasparini and Margolies, 1977.

Coricancha i jej astronomiczna orientacja według interpretacji A.F. Aveniego i R.T. Zuidemy. Jako podstawą do swoich analiz Autorzy ci ewidentnie posłużyli się wcześniej publikowanym planem Gasparini and Margolies, 1977).
Fig. 8. Coricancha. Schematic reconstruction of the places of the sunrise of May 25 and July 18 (Gregorian) as well as the Pleiades.

Coricancha. Schematyczna rekonstrukcja miejsc wschodu Słońca i Plejad 25 maja i 18 lipca (daty wg kalendarza gregoriańskiego), wg modelu A.F. Aveniego i R.T. Zuidemy (Aveni, 1981; Zuidema, 2010). 


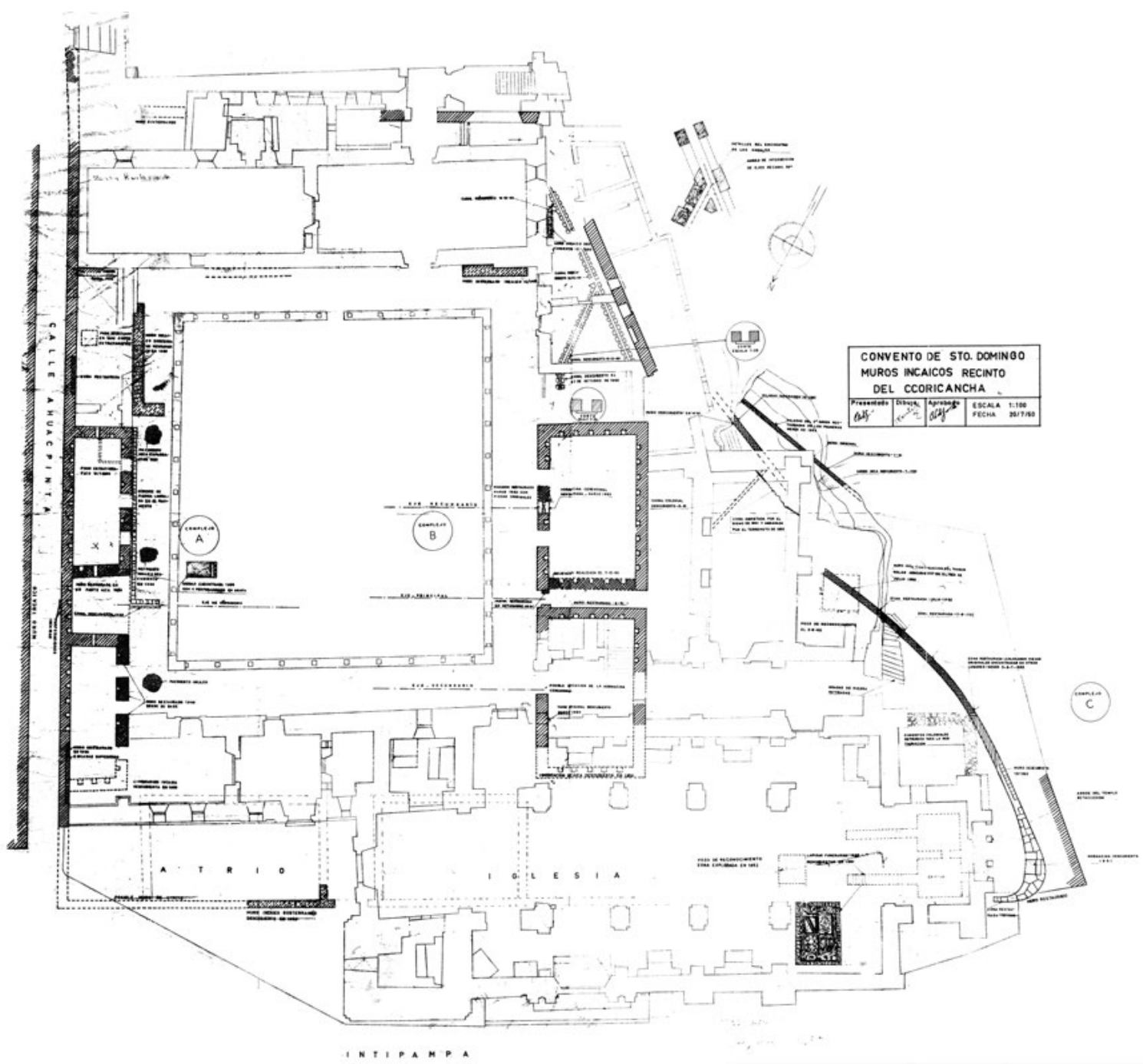

Fig. 9. Plan prepared by Oscar Ladrón de Guevara in July 1960 during his work on Coricancha restoration ${ }^{16}$.

Rzut sporządzony przez Oscara Ladrón de Guevara w lipcu 1960 roku w czasie prac rekonstrukcyjnych w Coricancha.

Before going any further, it is important to point out that due to surveying technics available at that time, none of the plans are accurate enough for precise archaeo-astronomical studies, particularly when it comes to the measurement of the angles between their constitutive elements (passageways, walls, etc.)

Having opted, apparently, for the plan by Gasparini and Margolies, Aveni and Zuidema proceeded to calculate their orientations through two solar observations - it is supposed in reference to some architectonic elements of Coricancha, easily recognisable on that plan. Nevertheless, there is still one doubt: where did they make their observations from? In other words: where did they place their transit instrument (theodolite) to observe the sun, determine the eastern horizon's height, etc.? These questions lead us to the following one: how would the Inca people make their observations of the sunrise in the directions (and on the dates) that were considered important for the Zuidema/Aveni model? Or, in other words: in which exact place would the Incan priest-astronomer have to be ready to observe sunrise and the Pleiades from the passageway between the two ceremonial structures situated on the western side of Coricancha's terrace? 
To answer these questions, we can only make some suppositions based on the schematic drawings published by the above-mentioned scholars to illustrate their hypothesis (Fig. 7 and 8). From these we can clearly state that they could have been hardly 'accurate' observations for two main reasons:

- first, the line of sight established by the above-mentioned passageway ${ }^{17}$ did not point at the horizon but to a point situated 3 degrees below,

- second, in that direction on the horizon, there is no natural object (prominent rock, etc.), nor information about the existence in the past of any artificial structure like a sucanca, that could have served as a reference point for the observations.

With these limitations, the only way to establish the more or less exact dates of the sun's transit through the aforementioned corridor would be by observing the shadow projected by the jambs of its eastern door at sunrise. However, this would have been an approximate orientation, much less precise than the one that could have been obtained with the astronomical equipment of Inkaraqay and Intimachay mentioned above.

Leaving aside, for the time being, the technical issue of the alleged observations and their practical goal, let us come back to the main matter, i.e. the orientation of these parts of the temple. In 2011 and 2012, as part of the architectonic documentation project of the Coricancha carried out by a group from the Centre of Pre-Columbian Studies at Warsaw University, a 3D scan of the whole ceremonial complex was done ${ }^{18}$. Based on that data, a plan of the whole Coricancha had been prepared and referenced to geographical North through 15 observations of the Sun disc made from the main court of the temple using a theodolite with a digital display. When it comes to the orientation of the Coricancha's structures, these new measurements differ widely from Zuidema and Aveni's ideas. To make it clearer, the debate about this critical topic is presented in several points.

The most significant difference is within the corridor of the western building $s^{19}$. This passageway is not oriented towards an azimuth of $66^{\circ} 44^{\prime}$ but of $67^{\circ} 06^{\prime}$. This difference of almost $22 \mathrm{MOA}$ means that the line postulated by Aveni and Zuidema doesn't point to the sunrise on the $25^{\text {th }}$ May and $18^{\text {th }}$ July but on the $23^{\text {rd }}$ May and $19^{\text {th }}$ July ${ }^{20}$. Therefore, the time that lapses between the successive sun passages (at its rises) through the corridor axis, an event that was very important to Zuidema (Zuidema 2010: 131ff.) changes from 55 to $57 / 58$ days. Digressing slightly, let us try to answer a basic question, which is: where are all these very significant differences coming from, at least in the archaeo-astronomical studies, between the results of Zuidema and Aveni and ours? Could an expert in archaeo-astronomy such as Aveni have been wrong in making observations about the sun? The answer is: no; his measurements, which served him as a reference, are accurate, they are almost the same as ours. The problem is down to the drawings that our colleagues used. That is:

1. As we have pointed out previously, because of time and logistical limitations, our colleagues did not have the opportunity of making their own survey of Coricancha (or, at least, of the temple's central patio and the corridor), but they used the already existing plan of Gasparini and Margolies from 1977.

2. To orientate this plan with exact geographical North, they took solar measurements, installing a theodolite on the roof of the Coricancha's church ${ }^{21}$, and like this, they concluded the exact orientation of the roof's axis, assuming that this matched exactly the one in the nave of the building at ground level. This theory was used as the basis of the final orientation of the plan. To reconstruct what is at the root of this method, we must remember that contemporary buildings east of Coricancha prevent direct observation of this section of the horizon directly from the corridor in question. However, the eastern horizon

17 By the way: with the observer located in which place of the corridor? At its western end, or on the contrary, on the east side, in the door leading from the patio?

18 The Centre is collaborating with the Authorities of the Convent of Santo Domingo of Cusco since 2006, carrying out a series of research works mainly in matters of diagnosis of the state of conservation of the historical patrimony of the Coricancha. The study of the architectura part was carried out in the years 2011-2013, within the framework of a project led by Sławomir Świeciochowski, who obtained for this purpose a grant from the National Science Centre of Poland. Specialists from several Polish scientific institutions took part in the project.

19 It is noteworthy that the expression "the facade looks" in this or that direction, means in practice that the line perpendicular to the facade points to a given place on the horizon. Without going into the details of this topic, note only that the new measurements differ a bit from those presented by Aveni and Zudiema: the eastern façade of the patio actually looks at $247^{\circ} 47^{\prime}$ (and not $248^{\circ} 13^{\prime}$ ), whereas in case of the western one, the difference is smaller, $66^{\circ} 41^{\prime}$ instead of $66^{\circ} 44^{\prime}$. See the following note.

20 That, considering the moment of departure of the star from the moment of appearance of its first rays on the horizon, as represented by Aveni in his reconstruction of the phenomenon (Aveni, 1981; Zuidema 2010: 131). In 1500 AD, these phenomena occurred, on dates of the Julian calendar, on May 14 and July 10, respectively (reconstruction carried out with the Cartes du Ciel 3.6 program and Stellarium 0.12.4).

21 Anthony F. Aveni confirms this in a personal communication (Aveni, letter from June 1, 2015). 
is clearly visible from the relatively easily accessible roof over the main nave of the church. In turn, by analysing the plan of Gasparini and Margolies, it is easy to see that the axis of the corridor is practically parallel to the nave axis of the main church set between the northern and southern pillars of the nave ${ }^{22}$.

3. The rest of the orientations (the axis of the corridor on the west side of the terrace, etc.) were established based only on the analysis of the aforementioned plan.

4. What the 3D scan of the Coricancha and the plan based on it made in 2012-2014 have revealed is that the axis of the temple's roof does not match the axis of the nave at ground level. The difference between both is $0^{\circ} 22^{\prime}$ (see Fig. 10 and 11$)^{23}$. In other words: projecting towards ground level the orientation established for the church's roof, the authors unwittingly introduced an error of $0^{\circ} 22^{\prime}$ in the orientation of their plan of reference ${ }^{24}$.

5. Other inaccuracies crept in while interpreting the aforementioned plan, whose precision, as we have already pointed out, was not enough for the goals of an archaeo-astronomical study.

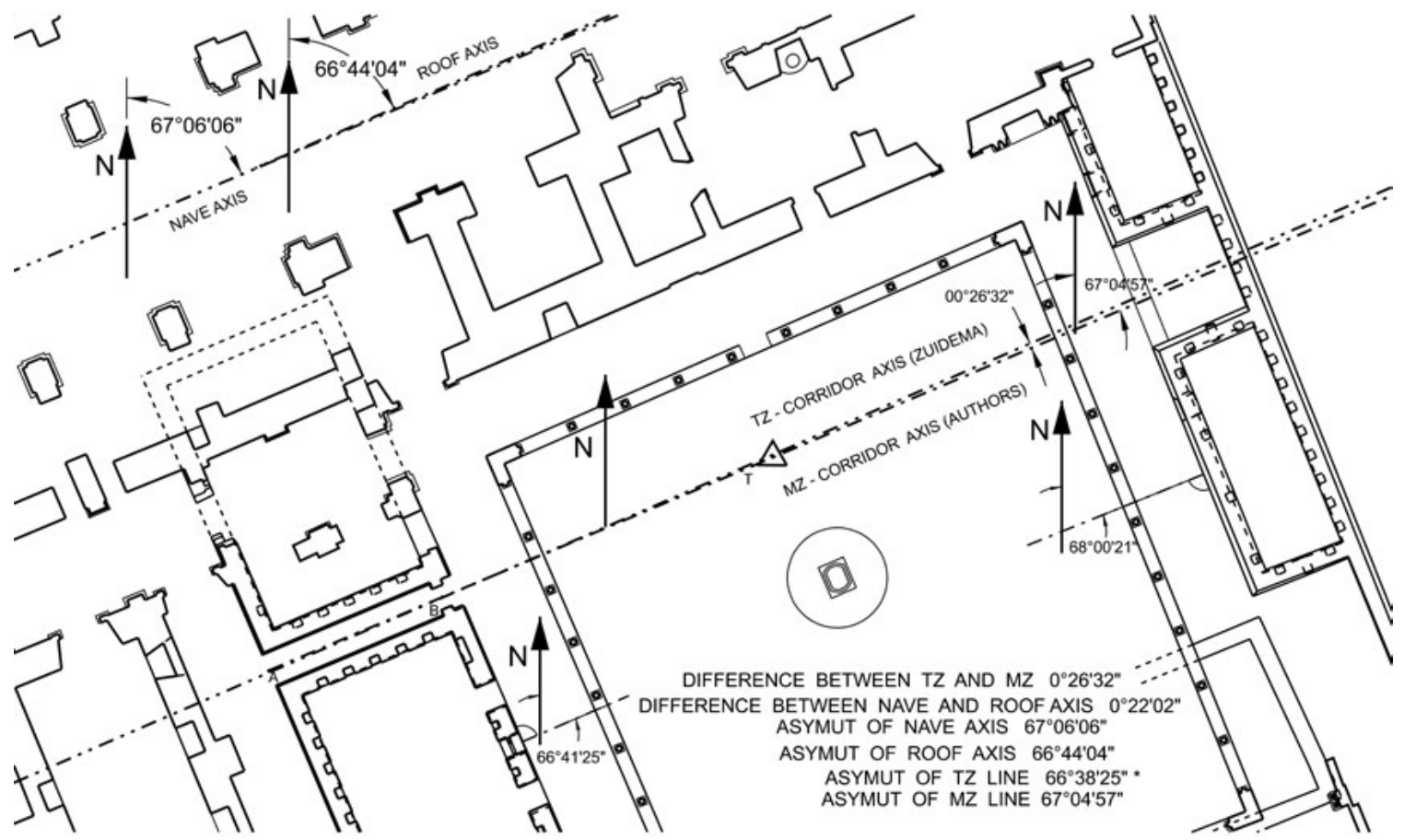

Fig. 10. Coricancha. Plan of the patio and the surrounding buildings with the orientations based on the new measurements taken in 2011-2012 and 2014. The precision of the orientations is of the order of \pm 2 MOA. Note, that the axis of the corridor points to azimuth $67^{\circ} 06^{\prime}$ and not $66^{\circ} 44^{\prime}$ as proposed by R.T. Zuidema The consequences of that are discussed in the text. (Prepared by J. Kościuk, B. Ćmielewski, M. Ziółkowski).

Coricancha. Rzut patio i otaczających je budynków zorientowany według nowych pomiarów z lat 2011 -2012 i 2014. Dokładność orientacji rzędu \pm 2 minut kątowych. Azymut osi korytarza to $67^{\circ} 06^{\prime}$ a nie $66^{\circ} 44^{\prime}$ jak sugerował R.T. Zuidema. Konsekwencje tej różnicy dyskutowane są w tekście. (Opracowanie: J. Kościuk, B. Ćmielewski, M. Ziółkowski).

22 This is confirmed by the results of our 3D laser scan from 2011-2012 - the difference in orientation between the two axes lies within 3'.

23 However, it should be admitted that this difference would be extremely difficult to grasp by classical measurement methods. It was revealed only by analysing 3D cloud of laser scanning points, representing the church's main aisle and the roof. The situation is further complicated by the fact that the pillars of the main nave of the church converge to the east at an angle of about 3 degrees.

24 It is worth mentioning that in a more recent work, A.F. Aveni had modified the axis orientation of the corridor and gave it a value close to the one we obtained, that is, a bit more than $67^{\circ}$ (Aveni, 1997), but R.T. Zuidema had apparently not taken into account this change, and continued using the previous value (Zuidema, 2010, 2014). 
All this has some important consequences, because, as has been previously stated, the two key points of all the quipu-calendar model, namely the date - May $25^{\text {th }}$ - as well as the time span of 55 days ${ }^{25}$, lose their relevance ${ }^{26}$. In short, this theoretical model remains without any archaeo-astronomical basis.

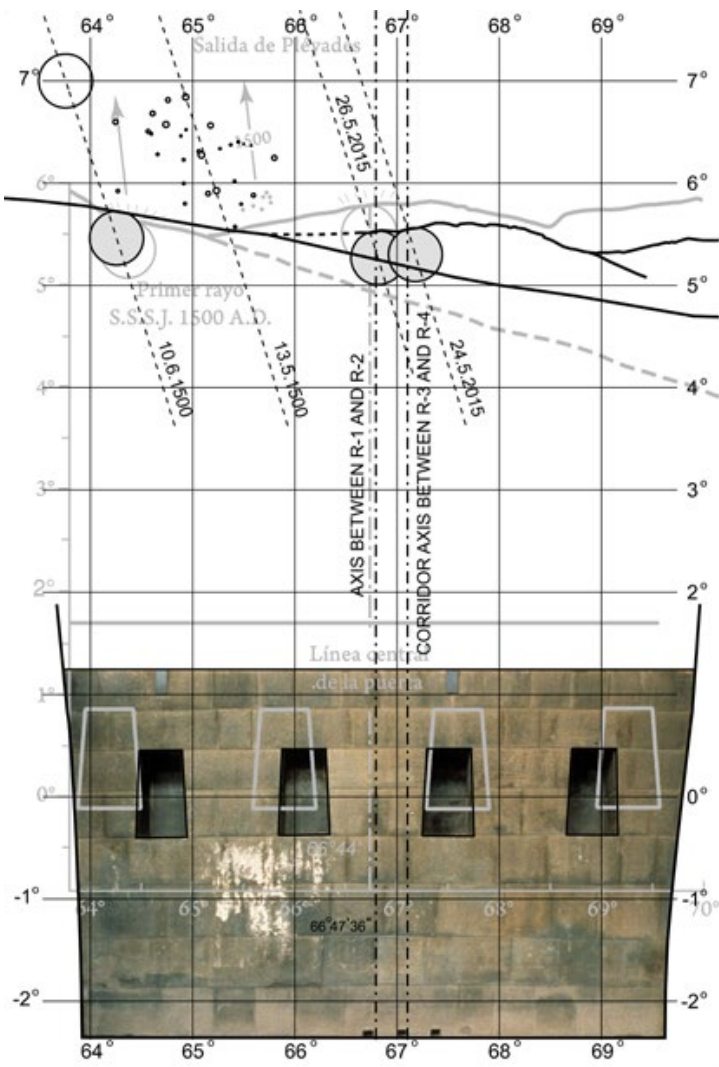

Fig. 11. Coricancha. Schematic reconstruction of the view towards the eastern wall of the patio and the horizon. In light grey-according to A.F. Aveni and R.T. Zuidema. In black and colour- according to J. Kościuk and B. Ćmielewski. Setting aside the difference in the orientation of $22 \mathrm{MOA}$ between the two estimations, the corridor between R-3 and R-4 could not be used for precise astronomical observations (prepared by J. Kościuk, B. Ćmielewski, M. Ziółkowski).

Coricancha. Schematyczna rekonstrukcja widoku w kierunku wschodniej ściany patio i horyzontu. Linie jasno szare: według A.F. Aveniego i R.T. Zuidemy; linie czarne: według J. Kościuka i B. Ćmielewskiego. Pomijając różnicę w orientacji rzędu 22 minut kątowych między obiema estymacjami, korytarz pomiędzy budynkami R-3 i R-4 nie mógł służyć do precyzyjnych obserwacji astronomicznych (opracowanie J. Kościuk, B. Ćmielewski, M. Ziółkowski).

\section{The seats of the Inca (and the Sun)}

The critical review of the hypotheses formulated about the possible function of Coricancha as a certain type of astronomical observatory gives somewhat disappointing results: either there are conjectures without a tangible archaeological basis, or, in the case of the hypothesis of 'quipu-calendar' the supporting arguments turned out to be rebuttable.

Let us then go back to the only historical reference, related directly to some device inside Coricancha, oriented towards the sun: the two 'seats of the Inca' (or, alternatively, of the effigy of the sun). As we have mentioned in the introductory part of this paper, the reference in question comes from two chroniclers of the $16^{\text {th }}$ century: Pedro Cieza de León and Bartolomé de las Casas. Both authors speak of a wall, provided with two seats or niches, which were illuminated by the sun at a certain moment of the day. The difference between these testimonies is that Cieza de León speaks of two seats facing the rising sun: 'two seats in that wall, which the sun illuminated on rising'.

On the other hand, de las Casas talks about niches on both sides of a wall, one illuminated at the sunrise while the other at the sunset: '... and on the wall, there was a niche where the image of the Sun was put, on the mornings, when the sun is rising. (...) and after noon they passed the image to the opposite part'. 
Leaving Coricancha for a moment, let us check if a device of this type, and with this function, has been registered in some undoubtedly Inca construction? The answer is positive, although the structure in the question is very far away from Cusco: it is the Inca temple of Ingapirca, in Ecuador.
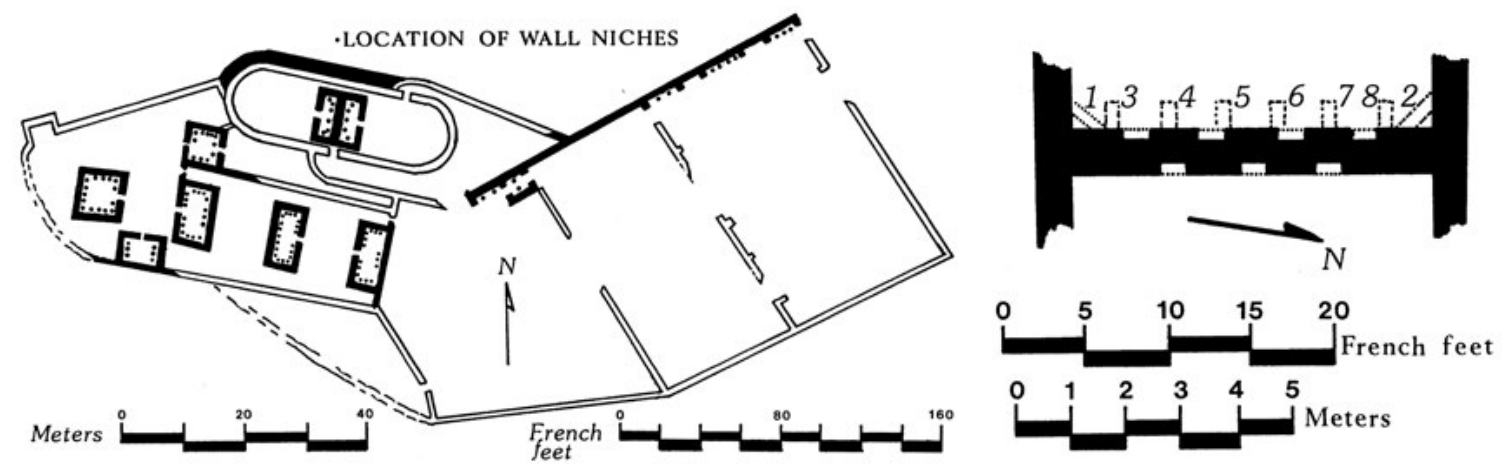

Fig. 12. The Castillo part of Ingapirca, according to Charles Marie de la Condamine. Left - the general layout of the compound. Right disposition of the niches in the transversal wall of 'Cuerpo de Guardia' (interpretation of the original La Condamine's plan by M. Barnes and D. Flemming, 1989).

Kompleks zwany „El Castillo w Ingapirca, wg Charles'a Marie de la Condamine (1742). Po lewej: ogólny rzut zespołu. Po prawej: układ nisz w murze działowym budynku "Cuerpo de Guardia" (interpretacja oryginalnego planu La Condamine'a wg M. Barnes i D. Flemminga, 1989).

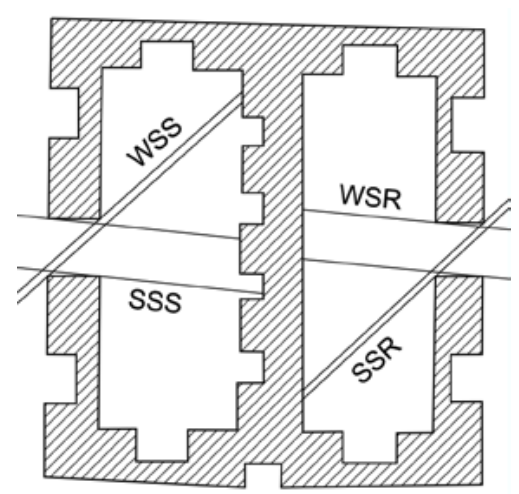

Fig. 13. The 'Cuerpo de Guardia' building with the representation of the alternative illumination of its rooms throughout the year (Ziółkowski, Sadowski 1991): WSS - December Solstice Sunset; WSR - December Solstice Sunrise; SSS - June Solstice Sunset; SSR - June Solstice Sunrise.

Rzut budynku "Cuerpo de Guardia" ze schematycznym przedstawieniem zmian w oświetleniu jego pomieszczeń w ciągu roku (Ziółkowski, Sadowski 1991): WSS - zachód Słońca w przesileniu grudniowym; WSR - wschód Słońca w przesileniu grudniowym; SSS - zachód Słońca w przesileniu czerwcowym; SSR - wschód Słońca w przesileniu czerwcowym.

The most notable building of the Ingapirca is the so-called 'El Castillo': a semi-elliptical platform, $36 \mathrm{~m}$ long and 4 meters high, with a stone wall erected with finely carved stones. At the top of the platform, in its middle part, there is a small building traditionally called 'Cuerpo de Guardia', or Guards' Room. This structure consists of two rooms without any communication between them, separated by a dividing wall. Both rooms are adorned, in their interior and exterior walls, with trapezoidal niches of various sizes.

The platform and the building above it have been the object of intense reconstruction and anastylosis works. Fortunately, we have a quite detailed plan of this compound, made already in 1746 by the French astronomer Charles Marie de la Condamine. This valuable document presents even the original arrangement of the niches in the transverse wall (Fig.12).

In the 1980s, a detailed archaeo-astronomical study of this temple was carried out by one of the Authors, in collaboration with the astronomer Robert M. Sadowski (Ziółkowski, Sadowski 1991). According to the results of this study (Fig. 13), it seems that the orientation of 'Cuerpo de Guardia' has been conceived in such a way that the two rooms of the building serve alternately during the year depending on the illumination of the central part (and niches) of the transverse wall by the rays of the Sun. The Eastern Room was illuminated by the rays of the rising sun in the period close to the December solstice (the orientation of the axis corresponding to the sunrise on November $13^{\text {th }}$ and January $30^{\text {th }}$ ) whereas the Western Room was illuminated by the setting sun in a period close to the solstice of June (the axis indicating the position of the sun on May $16^{\text {th }}$ and July $28^{\text {th }}$ ). 
Now let us go back to Coricancha: is there an architectonic element, similar in structure and function to the transversal wall (with niches) of 'Cuerpo de Guardia'? Let us remember that a special, portable, object of worship was kept in the Coricancha, which reflected the sun's rays: it is the figure called Punchao, the principal effigy of the solar cult of the Inca Empire. Punchao fell into the hands of the Spaniards in 1572 during the final attack on the last Inca redoubt of Vilcabamba and was later sent to Spain. Fortunately, we have a description, although short, of this effigy: 'The idol punchau is made of casting gold (...) it had a way of small shields of gold around it, so when the rays of the Sun reflected from them, they [the worshipers] could never see the idol but the radiance ... $)^{27}$. The information about the ceremonial importance of the radiance, produced by this solar image at the moment of being illuminated by the rays of the sun is confirmed by other sources ${ }^{28}$.

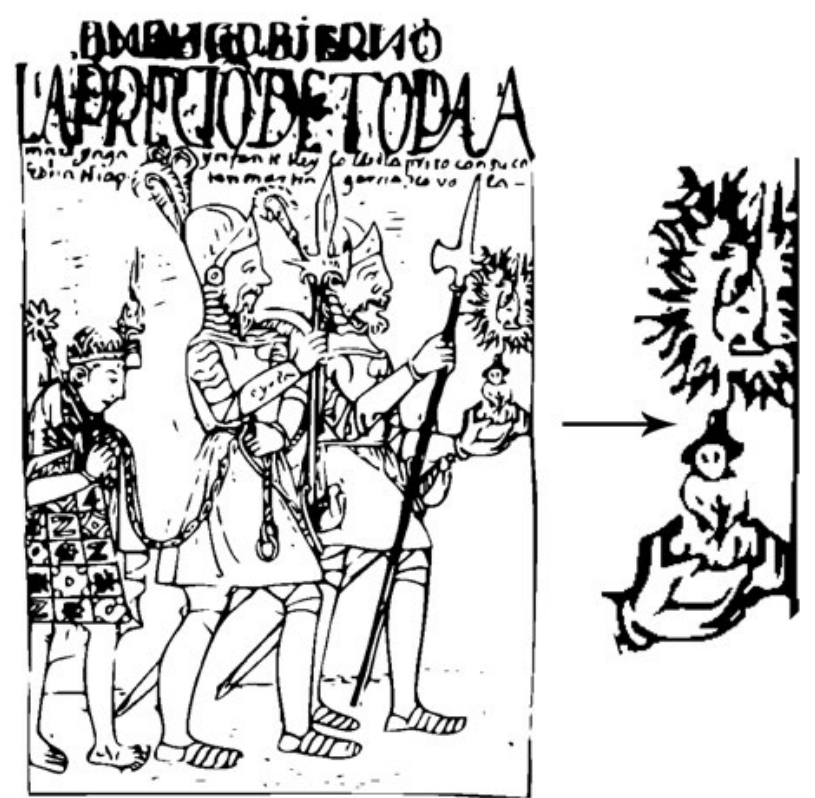

Fig. 14. The image of Punchao represented in a drawing by Guamán Poma de Ayala, entitled Pressure of Tupa Maru Inqa, infant, king. He is held prisoner with his crown by Captain Martin García de Loyola (Guamán Poma, fol. 449 [451]). The king walks barefoot, with his symbols of power. Another Spanish takes a small statue, above which an aureole of rays is represented. It indicates, that this is an effigy of the Sun, protector of the Inca dynasty. From the description in the letter of Francisco de Toledo (see in the text) it turns out that this was certainly the figure of the Punchao.

Przedstawienie Punchao na grafice Guamán Poma de Ayala zatytułowanej Uwięzienie Tupa Amaru Inqi, infanta i króla. Prowadzi go uwięzionego i z korona kapitan Martín García de Loyola (Guamán Poma, fol. 449 [451]). Król idzie boso dzierżąc symbole swojej władzy. Jeden z Hiszpanów niesie mały posążek nad którym widać aureolę światła wskazująca że jest to wyobrażenie Słońca - protektora inkaskich dynastii. Opis zawarty w liście Francisco de Toledo (patrz w tekście) potwierdza że jest to przedstawienie Punchao.

With this evidence in memory, we now return to Cusco and the Coricancha. Are there elements within this temple similar to those described by Spanish chroniclers? Trying to answer this question we must remember that only two buildings (Fig. 18; R2 and R3) are extant (although partially reconstructed) to the degree, which allows us to interpret their detailed layout. For another two ( $R$ and $R 4$ ) the northern perimeter walls are missing and their exact plan can be deducted only by analysing still preserved foundations (R4) or comparison with dimensions of the neighbouring one (R1). The only remains for other five structures $(R-A \div R-E)$ are partially preserved foundation walls - just enough to propose the general outline and position of these buildings, but nothing to judge about details of their exterior and interior arrangement.

The most inspiring description of Pedro Cieza de León tells us about '... two seats in that wall, which the sun illuminated on rising .... The only walls, which are eastwardly orientated are the ones of R-3 and R-4 forming ca. $30.25 \mathrm{~m}$ long section (Fig. 18). Its left (southern) part corresponds to R-3, while the right part (belonging to $\mathrm{R}-4$ ) is only partially preserved. In the centre of the former one, a niche is extant with evident traces of fittings (Fig. 4) meant to receive covering by gold plates, well attested by Spanish chroniclers. Oscar Ladrón de Guevara

27 The English translation we provide is an abbreviation of the somewhat longer original description: "El ydolo punchau que quiere dezir dia y es el del sol que dio las leyes del culto desde la la ciudad del Cuzco a todo el reyno (...) es de oro baziado con vn corazon de massa en vna caxica de oro de dentro de el cuerpo del ydolo y la massa de polvos de los corazones de los yngas pasados (...) tenia vna manera de patenas de oro a la redonda para que dandoles el sol relumbrasen de manera que nunca pudiesen ver el idolo sino el rresplandor ...)" (Francisco de Toledo, Carta al cardenal Sigüenza, Chicacopi, 19 octubre 1572 in: Roberto Levillier, 1924, t. IV, pp. 501-502).

28 The most important is that of the chronicler Juan de Betanzos, who also confirms the modest dimensions of this effigy: 'the size of $a$ oneyear-old child' (Betanzos 1987, p. I, Chap. XI, pp. 51-52). Compare also the drawing and a short description of the effigy by Guaman Poma (1615/1616 fol. 449-450 [451-452]. - Pierre Duviols carried out a detailed analysis of the existing historical relations about this figure, as well as about the possible modifications that were made on it during the reign of 7 or 8 Inca sovereigns (Duviols, 1976). See also the discussion on this matter in Ziółkowski, 2015, pp. 94-99. 
Aviles when preparing drawings for partial anastylosis of this wall decided to place the corresponding niche also in the northern section of this wall, which has finally not been reconstructed (Fig. 15). The similarity with the account of Pedro Cieza de León is striking - among still preserved or at least theoretically reconstructed architectural details of Coricancha these two niches are the only items, which might fit his description.

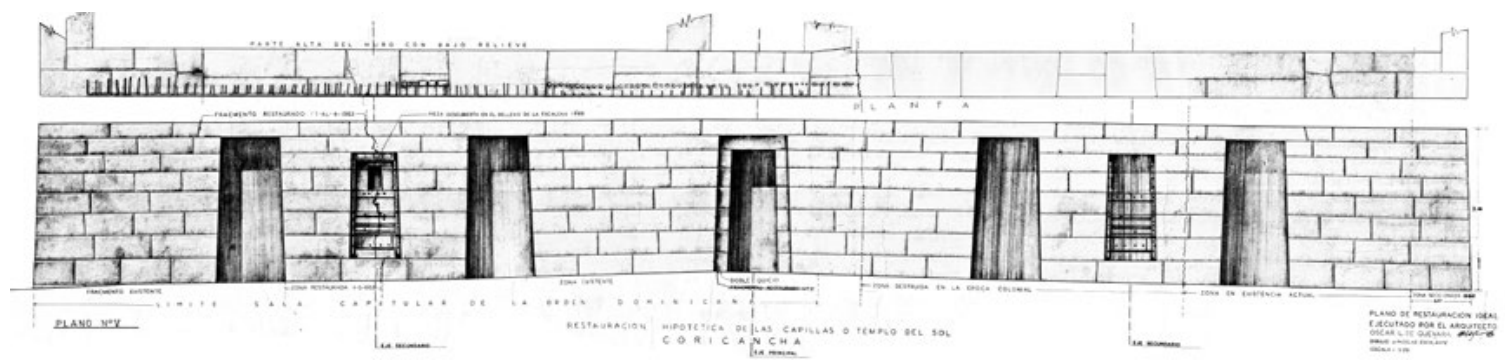

Fig. 15. Reconstruction of eastern façade of R-3 and R-4 prepared by Oscar Ladrón de Guevara Aviles during his work on Coricancha restoration in 1963.

Rekonstrukcja wschodniej elewacji budynków R-3 i R-4 sporządzona przez Oscara Ladrón de Guevara Aviles w 1963 roku w czasie prac konserwatorskich w Coricanchy.

Table 1. Table 1. Reconstruction of the position of the Sun above the eastern horizon as seen from the Coricancha Temple on 10.06.1500 AD (Julian date).

Rekonstrukcja pozycji Słońca obserwowanego ze świątyni Coricancha 10.06.1500 n.e. (wg kalendarza juliańskiego) nad wschodnim horyzontem.

\begin{tabular}{|c|c|c|}
\hline & $\mathbf{h}\left[{ }^{\circ}\right]$ & $\mathbf{V}\left[{ }^{\circ}\right]$ \\
\hline The first ray of the Sun & $64^{\circ} .228$ & $5: 724$ \\
\hline The centre of the solar disk on the horizon & $64^{\circ} .168$ & $5: 737$ \\
\hline The entire solar disk visible above the horizon (the center of the solar disk) & $64^{\circ}: 077$ & $6: 021$ \\
\hline $\begin{array}{l}\text { The centre of the solar disk above R-1 and R-2 roofs and sun's rays roughly } \\
\text { perpendicular to the eastern façade of R-3 and R-4 (ca. } 1 \text { month before and } \\
1 \text { month after the June solstice) }\end{array}$ & ca. $66^{\circ} 7$ & ca. 11.5 \\
\hline
\end{tabular}

Only right side of the famous niche of the so called 'Enclosure of the Stars' is fully preserved, while the left side has been only partially reconstructed leaving two holes in the central part. There is rather no doubt that there has been another stone block, now missing, filling the lower gap. The upper hole is a window well attested by the shape of the small lintel missing on the photo from 1942 (Fig. 4 - the photo on the left side) but found in 1960 by Oscar Ladrón de Guevara in a backfill of the staircase (Fig 15 - Oscar Ladron annotation above the lintel).

What might have been its function? There are two possibilities: to illuminate the interior of the room R-3 during a specific period of the year and moment of the day, or to observe, from the inside of the room, a specific part of the (night?) sky.

But for what purpose? With regards to the first possibility, certainly not for illumination of some objects in the niches in the inner, western wall of the room. It would only be possible with a flat eastern horizon, and this isn't the case. Since the sills of the niches are on the same height as the lower part of the discussed opening, the sun's rays will never illuminate the niches (see fig. 16 and table 1). Taking into account the roofs of the buildings located on the eastern side of the patio, the sun's rays will illuminate only the part on the wall below niches, or the floor or the room R-3. For the purpose of precise observations of the rising Sun some additional structural elements inside this room would be necessary e.g. markers (lines?) on the wall and / or the floor.

It is worth noting here that the chronicler Sarmiento de Gamboa mentions the existence in the area of Cuzco of a gnomonic device with such characteristics: 
... considering where the sunlight fell through those holes at the time of fallowing and planting, he made marks on the ground [...]. And as he had adjusted these posts precisely, he put for permanence in their place some stone columns with the [same] measurements and holes as the posts, and all around he ordered the ground paved, and on the stones made certain leveled lines conforming to the movements of the sun which entered the holes [...]. And he delegated people to take charge of these clocks... (Sarmiento de Gamboa 1906, Chap. 30 [1571] - English translation according to Bauer and Dearborn 1995: 37).

We postulated the existence of similar observation system in the case of the observatory at El Mirador de Inkaraqay (Astete, Ziółkowski, Kościuk, 2016/2017, pp. 20-21).

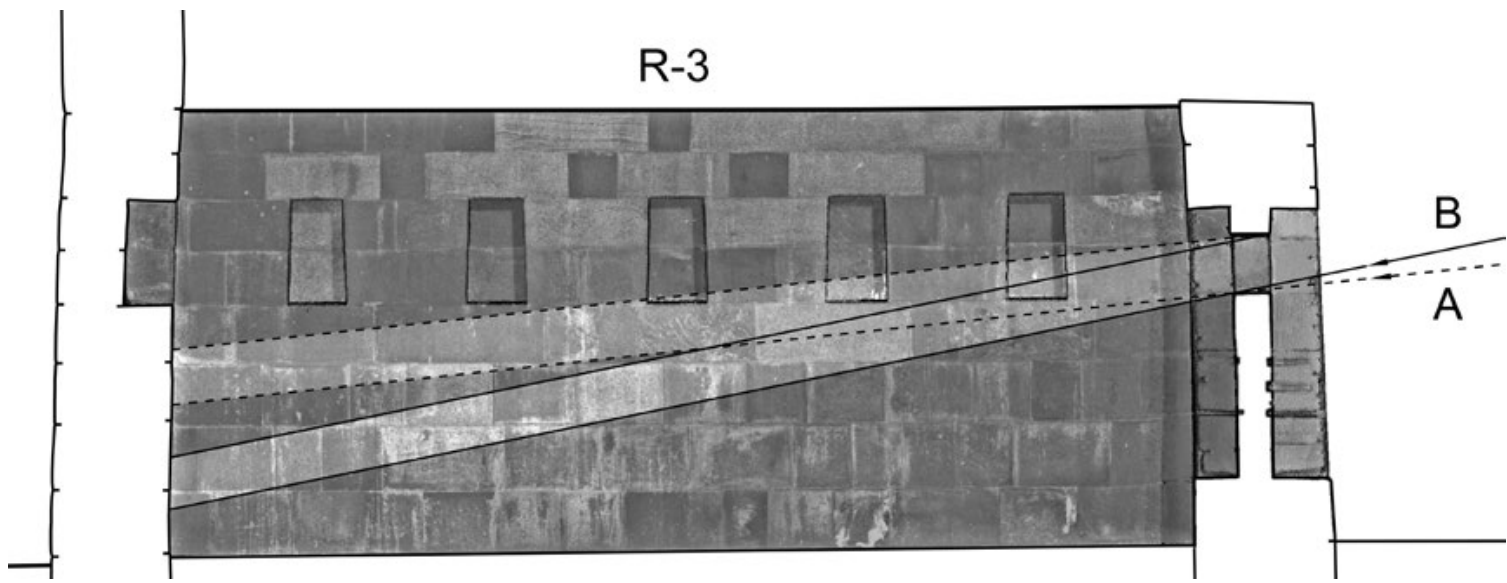

Fig. 16. E-W section across R-3 building with the simulation of sun rays on the day of the June solstice. A - the theoretical direction of the sun's rays at the moment of rising above the horizon, $\mathrm{B}$ - the actual direction of sunlight taking into account the existence of roofs over R-1 and R-2. Angular data according to Table 1. (Prepared by J. Kościuk).

Przekrój W-Z przez budynek R-3 z symulacją padania promieni słonecznych w czasie przesilenia czerwcowego. A - teoretyczny kąt padania pierwszych promieni słonecznych w momencie wschodu słońca nad linią horyzontu. B - faktyczny kąt padania pierwszych promieni słonecznych biorący pod uwagę dachy nad budynkami R-1 i R-2. Dane kątowe według Tabeli 2 .

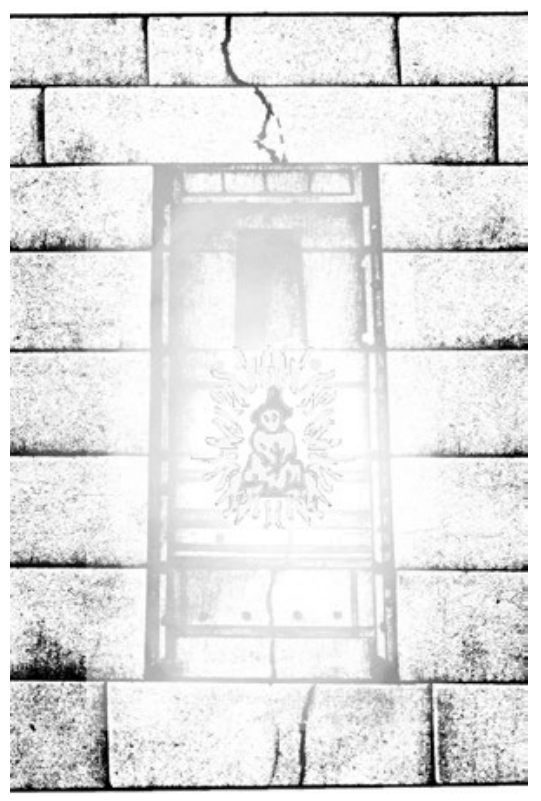

Fig. 17. Theoretical reconstruction of Punchao placed in the niche of the eastern façade of the so called 'Enclosure of the Stars'. (Prepared by J. Kościuk. Fragment of Oscar Ladrón de Guevara Aviles reconstruction used as a background) 
On the other hand, it seems very likely that the niche in the R-3 facade (and the alleged second one, in the R-4 façade), both covered with gold plates, served to achieve already mentioned radiation effect, so desired from the ceremonial point of view. Looking for places which might fit Pedro Cieza de León description of '... two seats...' this might be the best choice. Perhaps not inside the niches, but rather in front of them since the niches are too narrow and too shallow for humans to seat comfortably in ${ }^{29}$. What might, however, fit well into the seats in the niches, is mentioned above the statue of Punchao - the effigy of Sun attested by many sources as being kept in Coricancha (Fig. 17).

The most spectacular effect of Punchao and niches radiating in sun-light will be when sun rays are nearly perpendicular to the wall surface. The normal to the wall in question is at the azimuth $66^{\circ} 41^{\prime}{ }^{\prime 2} 5^{\prime \prime}$ (Fig. 11), so the niches will be in full, perpendicular sun-light for at least one month before and one month after the June solstice, roughly one hour after the astronomical sun rise due to R-1 and R-2 roofs obscuring the eastern horizon.

Still remains the critical analysis of the second account - that of Bartolomé de las Casas describing '... a niche where the image of the Sun was put, in the mornings, when the sun is rising. (...) and after noon they passed the image to the opposite part, in another lace, so the setting Sun faces the effigy...'. Although the existence of similar niches is attested by the quoted above Ingapirca example (Fig. 13), there is no room for such the arrangement within the perimeter of Coricancha (Fig. 18).

Let us now consider the second possibility, i.e. the observation of a specific part of the night sky from inside of the room R-3. Of course, the observed section of the sky changed, depending on the place where the observer stood (or rather sat) inside of the room. Reconstructing the situation at the beginning of June $1500 A D$, we note that an observer, sitting at the foot of the inner western wall of the R-3 room, a little bit $S$ of the axis of the window, could have seen, close to the inner left border of the window, the rising Pleiades at a height of about 10 degrees above the horizon, it means, above the roofs of buildings on the eastern side of the patio. However, the problem what could be observed through this window in the night sky, requires further analysis.

\section{Conclusions}

Let us then return to the question already asked in the title of this paper: are there evidences that accurate astronomical observations have been performed within the Coricancha Inca compound? And if so, of what kind? We can answer this question in points:

1. As we have shown above, in the preserved remnants of the original, indisputably Inca buildings of Coricancha, we do not find elements, but one (see below p. 5), that could be used for precise astronomical observations, nothing similar to the well documented observatories of Intimachay and El Mirador of Inkaraqay (both in the Park National Machu Picchu) ${ }^{30}$

2. The hypothesis of A.F. Aveni and R.T. Zuidema that the corridor between buildings R-3 and R-4 on the west side of the central patio filled this kind of function (compare Fig. 7) can't stand criticism. First, the line of sight established by the above-mentioned passageway did not point at the horizon but to a point situated 3 degrees below. Second, in that direction on the horizon, there is no natural object (prominent rock, etc.), nor information about the existence in the past of any artificial structure like a sucanca, that could have served as a reference point for the observations. Finally, the direction designated by the corridor axis does not correspond to the dates postulated by Aveni and Zuidema of the sunrise on May 25 and July 18, the key for the calendar part of their hypothesis related to the presumed 328-day quip-calendar cycle.

3. Of course, one can't exclude the possibility, that such a kind of accurate observations were performed from an unidentified place of the western part of the Coricancha, for example in the relation with a sukanka erected in an adequate place on one of the hills to the West of the temple. However, there are no archaeological evidences that could firmly support this hypothesis.

4. On the other hand, the information provided by the Spanish chronicler Pedro Cieza de León, about the existence in Coricancha of two 'seats' lit by the rising sun seems to be confirmed. The finely decorated 
niche in the façade of the building R-3 fits well this historical description. The second such a niche/seat may have been positioned in the northern part of this wall, now unfortunately destroyed, of the building R-4 (Fig 16). However, it should be emphasised that even in this case it is difficult to talk about precise astronomical observations, but rather on a visual effect (blinding glare), a performance important within the frame of the Inca solar cult (Fig. 15).

5. The only existing original architectonic element, that can be used for more precise observations, is the window in the niche in the façade of the building R-3. It should be noted that a window so small in size could not be placed by builders in such a special place without a precise and specific purpose. The observation function seems very likely here. Two, not mutually exclusive, hypotheses can be considered: it was either for gnomonic observations of the Sun's rays falling into the room at sunrise, or observations from within the building R-3 of a specific fragment of the night sky. However, both hypotheses will require further research to determine, what kind of event and/or celestial bodies were indeed subject to observation.

\section{Final remarks}

What we have presented in the present paper is only part of a multidisciplinary study on Coricancha, whose results we hope to publish soon. However, it seemed important to present to the public an alternative view of the supposed astronomical function of this temple, a hypothesis extant for many years in the literature of the subject, and widely accepted without prior critical evaluation of its bases.

But it is to be emphasised that our predecessors, with the means available at that time, made a careful study, formulating an interesting hypothesis about the Inca sky-lore and calendric. If with the passage of time, the new data are forcing us to review the previous postulates, this does not reduce the importance of the scientific contribution of the aforementioned scholars. They opened a research path, which others are now following.

\section{Acknowledgements}

The research described above was carried out in several phases between 2011 and 2017. In the years 2011-2013, laser scanning of the entire complex and the basic archival and bibliographic query were financed under the grant of the National Science Centre of Poland ${ }^{31}$ for the research project 'Qorikancha - a complex historical and architectural study of the former Temple of the Sun in the capital of the Inca state, Cusco (Peru)' headed by architect Sławomir Święciochowski, PhD, associate researcher of the Centre for Precolumbian Studies of the University of Warsaw (OBP UW). In subsequent years, i.e. 2014-2017, the researches were sponsored within the BST funds of the OBP UW. The research team also used the infrastructure and equipment of the Centre for Andean Studies of the University of Warsaw in Cusco (CEAC) as well as of the Laboratory of 3D Laser Scanning and Modeling of Wroclaw University of Science and Technology (LabScan3D) - both sponsored under the SPUB grants by the Ministry of Science and Higher Education of Poland.

We would like to thank the Community of the Dominican Friars in Cusco, and especially the then Prior of the Qorikancha-Santo Domingo convent, Fray Luis Enrique Ramirez Camacho, for their comprehensive help. We are also extremely grateful to Mr César Ladrón de Guevara for the release of the highly valuable plans and photos of Coricancha, from his Fathers', Oscar Ladrón de Guevara, private archive. Finally, last but not least, we would like to thank Professor Anthony F. Aveni for providing us with information about the fieldworks in Coricancha carried out by him and late Professor Tom Zuidema in 1976 and 1980. 


\section{Annex. Preliminary observations on Coricancha metrology}

As a conclusion of a methodological nature, it is important to underline the importance of new technologies, such as 3D laser scanning, particularly for the study of complex architectural structures like the Coricancha Temple. Beside precise measurements giving a good starting point to verify earlier surveys, it results in the abundant amount of data which might be used also for metrological studies.

Table 2. Comparison of Coricancha main walls dimensions.

Porównanie długości głównych ścian świątyni Coricancha.

\begin{tabular}{|c|c|c|c|}
\hline \multicolumn{2}{|c|}{ Our measurements ${ }^{A}$} & \multirow{2}{*}{\multicolumn{2}{|c|}{$\begin{array}{l}\text { Farrington data }^{B} \\
\qquad \text { length }[\mathrm{m}]\end{array}$}} \\
\hline wall & length [m] & & \\
\hline N1 & 84.58 & $\mathrm{~N}$ & 74.30 \\
\hline N2 & 87.61 & & \\
\hline$E$ & 70.57 & $E$ & 41.90 \\
\hline S1 & 41.03 & $\mathrm{~S}$ & $?$ \\
\hline $\mathrm{S} 2$ & 85.61 & & \\
\hline W1 & 69.34 & W & 85.60 \\
\hline W2 & 87.70 & & \\
\hline
\end{tabular}

A According to the results of our 3D laser scanning project. Please note that $\mathrm{N} 2+\mathrm{E}+\mathrm{S} 1+\mathrm{W} 2=286.91 \approx 400$ single steps (of ca. $72 \mathrm{~cm}$ ) mentioned by Pedro Cieza de León in his description of Coricancha (Cieza, II p., Cap. XXVII: 105-107)

B Farrington 2013, p. 170.

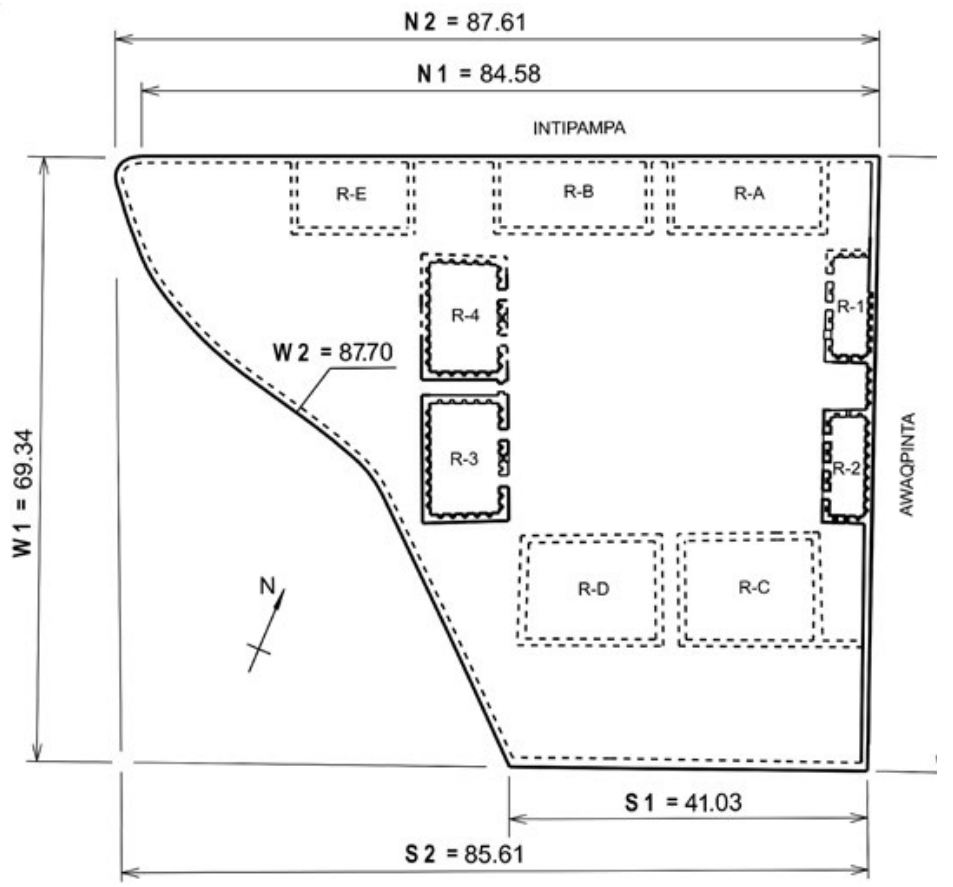

Fig. 18. Coricancha enclosure dimensions according to 3D laser survey. Lettering corresponds with Farrington naming convention (prepared by J. Kościuk).

Wymiary muru obwodowego Coricancha według wyników laserowego skanowania 3D. Oznaczenia literowe zgodne z konwencją nazw przyjętą przez I. Farringtona. (Opracowanie J. Kościuk).

According to the archaeological and historical data, "it is estimated that the temple enclosure dimensions were north side, $74.3 \mathrm{~m}$ (46r); west, $85.6 \mathrm{~m}$ (53r); and east, $41.9 \mathrm{~m}$ (26r)" (Farrington 2013, p. 170).

At this point, we must admit that there must be apparently a confusion between dimensions of particular walls given by Farrington. The following table (Table 2) and the plan (Fig. 18) illustrate the differences we noticed. The plan is based on an original drawing of Oscar Ladrón de Guevara (Fig. 9) kindly provided to the 
Authors by his son D. César Ladrón de Guevara and adjusted according to the results of 3D laser scanning project done in 2011-2014 ${ }^{32}$. It should be stated however that results presented in Table 2 depend greatly on the way the measurements were taken - at the foot of the wall, at a certain height above the ground or on the foundation level.

Following the presented above measurements of different parts of Coricancha, we are tempted to summarize these observations from the metrological point of view. Although our general study on Coricancha metrology is still not finished, some primary observations can be already offered, especially that they might be useful for any further archaeo-astronomical studies on Coricancha where not all the walls and details are fully preserved.

To begine, we can analyse the already quoted Coricancha main walls dimensions (Table 2). In his Cusco publication, Farrington gave dimensions of main Coricancha walls both, in meters and rikra (Farrington 2013, p. 170). Following these data, one arrives at the averaged rikra length of $1.614 \mathrm{~m}$ (Tabele 3). Using an analogous procedure in relation to our measurements we get rikra of $1.649 \mathrm{~m}$. At this point, however, we must remind that none of these measurements was taken on the foundation level where possibly one could trace the original measurement units used by Inka builders. This may explain differences in reconstructing the length of the original measuring unit (rikra) - so, these results should be not considered as conclusive.

Table 3. Estimation of rikra length based on dimensions of Coricancha main walls.

Estymacja miary rikra na podstawie długości głównych ścian świątyni Coricancha.

\begin{tabular}{|c|c|c|c|c|c|c|c|}
\hline \multicolumn{4}{|c|}{ Farrington data ${ }^{A}$} & \multicolumn{4}{|c|}{ Our measurements ${ }^{\mathrm{B}}$} \\
\hline Wall & $\begin{array}{c}\text { Length } \\
\text { [m] }\end{array}$ & $\mathbf{n}$ & rikra $[\mathbf{m}]$ & Wall & $\begin{array}{c}\text { Length } \\
\text { [m] }\end{array}$ & $\mathbf{n}$ & rikra $[\mathrm{m}]$ \\
\hline \multirow[t]{2}{*}{$\mathrm{N}$} & 74.30 & 46 & 1.615 & N1 & 84.58 & 51 & 1.658 \\
\hline & & & & N2 & 87.61 & 53 & 1.653 \\
\hline$E$ & 41.90 & 26 & 1.612 & $E$ & 70.57 & 43 & 1.641 \\
\hline \multirow[t]{2}{*}{ S } & $?$ & $?$ & & S1 & 41.03 & 25 & 1.641 \\
\hline & & & & S2 & 85.61 & 52 & 1.646 \\
\hline \multirow[t]{3}{*}{ W } & 85.60 & 53 & 1.615 & W1 & 69.34 & 42 & 1.651 \\
\hline & & & & W2 & 87.70 & 53 & 1.655 \\
\hline & verage rik & & 1.614 & & average rik & & 1.649 \\
\hline
\end{tabular}

A - Farrington 2013, p. 170. B - According to the results of after mentioned 3D laser scanning project.

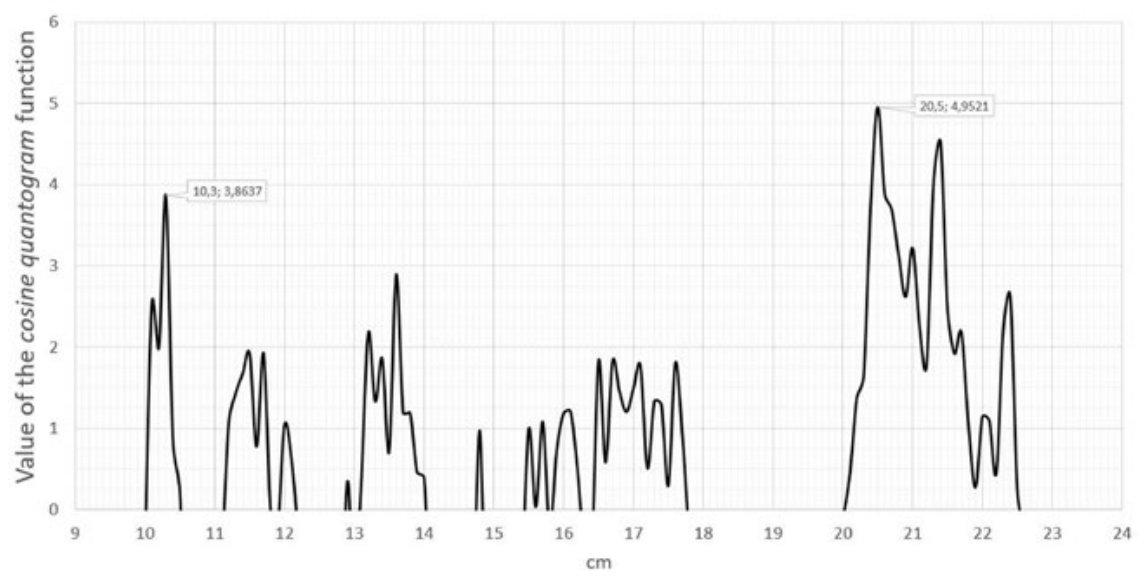

Fig. 19. Estimation of quanta for Coricancha main walls.

Estymacja quanta dla głównych ścian Coricancha.

32 The project has been executed in 2011 by Janusz Janowski and Marta Bury of the Institute of Archaeology of the University of Warsaw with Leica ScanStation 2 facilitated by the Institute of Archaeology of the University of Warsaw and completed in 2012-2014 by Jacek Kościuk and Bartłomiej Ćmielewski from the Department of History of Architecture, Art, and Technology of the Wroclaw University of Science and Technology (Poland) with Leica ScanStation C10. 
It is intriguing, that rikra equal to $1.649 \mathrm{~m}$ corresponds with our reconstruction of rikra length based on niches spacing and dimensions of original (not reconstructed) walls of Coricancha, where a much larger set of measurements has been analysed ${ }^{33}$. The cosine quantogram method (Kendall 1974; Pakkanen 2001) was used for these estimations (Fig. 19). Two local maxima of cosine quantogram function were detected. The first $(10.3 \mathrm{~cm})$ is corresponding with incaic unit $y u k u$, the second $(20.5 \mathrm{~cm})$ fits well with another unit - k'apa.

Since the system of ancient incaic units seems to be based on multiplication by factor 2 (Agurto 1987; Baudin 2003; Rostworowski 1978; Rowe 1946), therefore we can attempt to reconstruct the whole system using the first two items of the series. The length of rikra reconstructed in this way will be around $1.64 \mathrm{~m}$ (Table 4).

Table 4. Reconstruction of rikra length based on cosine quantogram estimation for Coricancha main walls.

Rekonstrukcja miary rikra metodą cosine quantogram na podstawie długości głównych ścian świątyni Coricancha.

\begin{tabular}{|cc|}
\hline Unit & Length [cm] \\
\hline rikra & $\mathbf{1 6 4}$ \\
\hline sikya & 82 \\
\hline khocok & 41 \\
\hline k'apa & $\mathbf{2 0 . 5}$ \\
\hline yuku & $\mathbf{1 0 . 3}$ \\
\hline
\end{tabular}

Table 5. Reconstruction of yuku length based on dimensions of the so called "Enclosure of the Stars" niches.

Rekonstrukcja miary yuku na podstawie wymiarów nisz w tzw. „Enclosure of the Stars”.

\begin{tabular}{|c|c|c|c|c|c|}
\hline & $\begin{array}{c}\text { Width at } \\
\text { the bottom } \\
{[\mathrm{cm}]}\end{array}$ & Height [cm] & $\begin{array}{l}\text { Width at } \\
\text { the top } \\
{[\mathrm{cm}]}\end{array}$ & Depth [cm] & $\begin{array}{l}\text { Height of the window } \\
\text { above the bottom of } \\
\text { the niche }[\mathrm{cm}]\end{array}$ \\
\hline EASTERN NICHE & 94.5 & 210.5 & 83 & 43.5 & 145.5 \\
\hline WESTERN NICHE & 93 & 211.7 & 84.5 & 32 & 145 \\
\hline $\begin{array}{c}y u k u \text { as calculated from } \\
\text { the dimensions of the } \\
\text { eastern niche }\end{array}$ & 10.5 & 10.5 & 10.4 & 10.9 & 10.4 \\
\hline $\begin{array}{l}\text { yuku as calculated from } \\
\text { the dimensions of the } \\
\text { western niche }\end{array}$ & 10.3 & 10.6 & 10.6 & 10.7 & 10.4 \\
\hline averaged yuku $[\mathrm{cm}]$ & 10.4 & 10.6 & 10.5 & 10.8 & 10.4 \\
\hline average $[\mathrm{cm}]$ & \multicolumn{5}{|c|}{10,5} \\
\hline
\end{tabular}
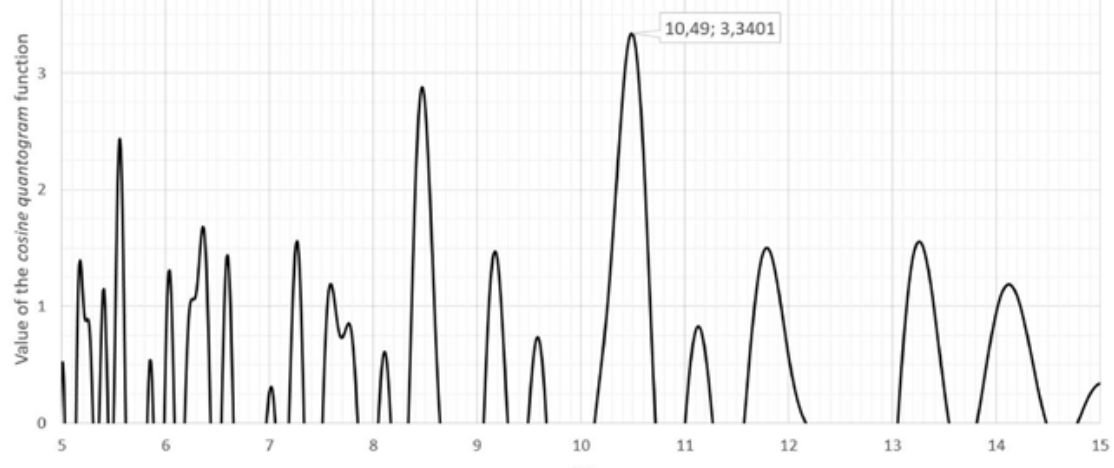

Fig. 20. Estimation of quanta for the so called 'Enclosure of the Stars' niches.

Estymacja quanta dla nisz tzw. "Sali Gwiazd”. 
Further on, we can continue with already mentioned, far more precise ${ }^{34}$ measurements of the niches in the east wall of the so called 'Enclosure of the Stars'. Using 25 measurements of both, the eastern and the western niches we are ending with the average length of yuku as $10.5 \mathrm{~cm}$ (Table 5). This, can be also verified by cosine quantogram method. The result of $10.49 \mathrm{~cm}$ (Fig. 20) confirms our previous estimation.

Using again multiplication by factor 2 , the length of reconstructed in this way rikra will be around $1.68 \mathrm{~m}$ (Tabele 6) - the value already suggested by Maria Rostworowski de Dies Canseco (Rostworowski, 1978).

Table 6. Reconstruction of rikra length based on cosine quantogram estimation for the so called 'Enclosure of the Stars' niches (Fig. 4).

Rekonstrukcja miary rikra metodą cosine quantogram na podstawie wymiarów nisz w tzw. „Enclosure of the Stars” (Fig. 4).

\begin{tabular}{|cc|}
\hline Unit & Length $[\mathbf{c m}]$ \\
\hline rikra & $\mathbf{1 6 8}$ \\
\hline sikya & 84 \\
\hline khocok & 42 \\
\hline k'apa & 21.0 \\
\hline yuku & $\mathbf{1 0 . 4 9}$ \\
\hline
\end{tabular}

To sum up all this information we can conclude that the most likely length of rikra was between 1.64 and $1.68 \mathrm{~m}$. Dividing these values in succession by 2 , we will get lengths for the remaining units of the metrological system which might have been used by Coricancha builders (Table 6).

\section{Bibliography}

Anónimo

1906 Discurso de la sucesión y gobierno de los Yngas", in: Juicio de límites entre el Perú y Bolivia, ed. Victor Maurtua vol. 8, pp. 149-165, Lima.

Agurto Calvo, Santiago

1980 Cusco: la traza urbana de la ciudad inca. Cusco, Proyecto Per 39, UNESCO, Instituto Nacional de Cultura, Cuzco.

Astete Victoria, Fernando; Mariusz Ziółkowski and Jacek Kościuk

2016/2017 On Inca astronomical instruments: the observatory at Inkaraqay - El Mirador (National Archaeological Park of Machu Picchu, Peru), Estudios Latinoamericanos, Sociedad polaca de Estudios Latinoamericanos, Warszawa, vol. 36/37 (2016/2017), pp. 9-25.

Aveni, Anthony F.

1981 Horizon Astronomy in Incaic Cuzco. In: Archaeoastronomy in the Americas, edited by Ray A. Williamson, A Ballena Press/Center for Archaeoastronomy Cooperative Publication, Los Altos - College Park, pp. 305-318

1997 Stairways to the stars: skywatching in three great ancient cultures, J. Wiley, New York, pp. 305-318.

Barnes, Monica and Fleming, David

1989 Charles-Marie de La Condamine's Report on Ingapirca and the Development of Scientific Field Work in the Andes, 1735-1744, Andean Past: Vol. 2, Article 10. Available at: https://digitalcommons.library.umaine.edu/andean_past/ vol2/iss $1 /$

Bauer, Brian S., and David S.P. Dearborn

1995 Astronomy and Empire in the Ancient Andes. University of Texas Press, Austin. 
Béjar Navarro, Raymundo

1990 Arquitectura Inka: El templo del Sol o Qorikancha, Consejo Nacional de Ciencia y Tecnología, Cuzco.

Betanzos, Juan de

1987 Suma y narración de los Incas, prólogo, transcripción y notas por María del Carmen Martin Rubio, Ediciones Atlas, Madrid.

Cieza de León, Pedro

1986[1550] Crónica del Perú, El Señorio de los Incas, p. II, Pontificia Universidad Católica del Perú, Lima.

Cornejo Bouroncle, Jorge

1942 El Ccoricancha, Revista Universitaria, vol. 31, nr 83, Cusco, pp. 74-84.

Dearborn, David S. P.; Schreiber Katharina J. and White Raymond E.

1987 Intimachay: A December Solstice Observatory at Machu Picchu, Peru. American Antiquity 52 (2), pp. $346-352$.

Duviols, Pierre

1976 Punchao, Ídolo mayor del Coricancha. Historia y tipología, Antropología Andina, n 1-2, Cusco, pp. 156-183

Farrington, lan

2013 Cusco. Urbanism and Archaeology in the Inka World, University Press of Florida.

Gasparini, Graciano and Margolies, Luise

1977 Arquitectura Inka, Universidad Central de Venezuela, Caracas.

Guaman Poma de Ayala, Phelipe

1980[1615/16] El Primer Nueva Coronica y Buen Gobierno, edición crítica de John V.Murra y Rolena Adorno, Siglo Veintiuno Editores, México.

Hyslop, John

$1990 \quad$ Inka Settlement Planning, Texas University Press, Austin.

Julien, Catherine

1996 Documentación presentada por la ciudad del Cuzco sobre el terremoto de 1650, Revista del Museo e Instituto de Arqueología, t. 25, Cusco pp. 293-373.

Kendall F.R.S., David George

1974 Hunting quanta, Philosophical Transactions of the Royal Society of London. Mathematical and Physical Sciences, 1974, A 276, pp. 231-266.

Kubler, George

1952 Cuzco: Reconstrucción de la Ciudad y Restauración de Sus Monumentos, Informe de la Misión enviada por la Unesco en 1951, UNESCO, Paris.

Levillier, Roberto

1924 Gobernantes del Perú, t. IV, Buenos Aires

Ladrón de Guevara A., Oscar

1967 La Restauración del Coricancha y Templo de Santo Domingo, Revista del Museo e Instituto Arqueológico, no. 21, UNSAAC, Cusco pp. 29-95. 
Lehmann-Nitsche, Roberto R.

1928 Coricancha, el templo del Sol en el Cuzco y las imágenes de su altar mayor. Revista del Museo de La Plata. v. XXXI, pp. $1-260$

Lízarraga, Reginaldo de

1968[1605] Descripción breve de toda la tierra del Perú, Tucumán, Río de la Plata y Chile. Biblioteca de autores españoles, vol. 216, Ediciones Atlas, Madryt.

Mena, Cristóbal de

1967[1534] La conquista del Perú [in:] Las relaciones primitivas de la conquista del Perú, ed. by Raúl Porras Barrenechea, Instituto Raúl Porras Barrenechea, Universidad Nacional Mayor de San Marcos, Lima, pp. 79-101.

Müller, Rolf

1972 Sonne, Mond und Sterne über dem Reich der Inka, Springer-Verlag, Berlin-Heidelberg-New York

Pakkanen, Jari

2001 Deriving ancient foot units from building dimensions: a statistical approach employing cosine quantogram analysis, in: Burenhult, G. and J. Arvidsson (eds.), Archaeological Informatics: Pushing The Envelope. CAA2001. Computer Applications and Quantitative Methods in Archaeology. Proceedings of the $29^{\text {th }}$ Conference, Gotland, April 2001, BAR International Series 1016, Archaeopress, Oxford, pp. 501-506.

Pizarro, Pedro

1978[1571] Relación del Descubrimiento y Conquista del Perú, Pontíficia Universidad Católica del Perú, Lima.

Rostworowski de Diez Canseco, María

1978 Mediciones y Cómputos en el Antiguo Perú, Cuadernos Prehispánicos No 6, Seminario Americanista, Universidad de Valladolid, Valladolid.

Rowe, John H.

1944 An Introduction to the Archaeology of Cuzco, Papers of the Peabody Museum of American Archaeology and Ethnology, vol. 27, nr 2, Harvard University, Cambridge Massachusetts.

1979 An account of the shrines of ancient Cuzco, Nawpa Pacha, vol. 17, Berkeley, pp. 1-80.

Ruíz de Arce, Juan

1933[1545] Relación de servicios en Indias de Don Juan Ruiz Arce, Conquistador del Perú, Boletín de la Real Academia de la Historia, 102, Madrid, pp. 327-384.

Sancho de la Hoz, Pedro

1962[1572] Relación de la Conquista del Perú, Bibliotheca Tenantitla 2, Ediciones José Porrua Turanzas, Madrid.

Sarmiento de Gamboa, Pedro

1906 [1571] Segunda Parte de la Historia General Llamada Índica. In Geschichtedes Inkareiches von Pedro Sarmiento de Gamboa, edited by Richard Pietschmann. Abhandlungen der Königlichen Gesellschaft der Wissenschaften zu Göttingen, Philologisch-Historiche Klasse, Neue Folge, Band VI nº 4. Weidmannsche Buchhandlung, Berlin.

Uhle, Max

1930 El Templo del Sol de los Incas en Cuzco [in:] Proceedings of the XXIII International Congress of Americanists in New York in 1928, New York, pp. 291-295.

Urton, Gary

$1981 \quad$ At the Crossroads of the Earth and the Sky, University of Texas, Austin. 
Ziółkowski, Mariusz

2015 Pachap Unancha. El calendario metropolitano del Estado Inca. Ediciones El Lector - Sociedad Polaca de Estudios Latnoamericanos, Arequipa.

\section{Ziółkowski, Mariusz and Sadowski, Robert}

1991 Investigaciones arqueoastronómicas en el sitio de Ingapirca, Prov. de Cañar, Ecuador, in: Archeologia e Astronomia, Colloquio Internazionale, Venezia 3-6 Maggio 1989, A cura di Manuela Fano Santi, Rivista di Archeologia Supplementi, 9, pp. 151-162.

\section{Ziółkowski, Mariusz, Jacek Kościuk and Fernando Astete Victoria}

2013 Astronomical Observations at Intimachay (Machu Picchu): A new approach to an Old Problem" In Ancient Cosmologies and Modern Prophets. Proceedings of the $20^{\text {th }}$ Conference of the European Society for Astronomy in Culture, edited by Ivan Sprajc and Peter Pehani, pp. 391-404. Slovene Anthropological Society, Ljubljana

2014 Inca Moon: Some Evidence of Lunar Observations in Tahuantinsuyu, in: Handbook of Archaeoastronomy and Ethnoastronomy, edited by Clive L.N. Ruggles, pp. 897-912. Springer Science+Business Media, New York.

Zuidema, R. Tom

1974-1976 La imagen del Sol y la huaca de Susurpuquio en el sistema astronómico de los Incas en el Cusco, Journal de la Société des Américanistes, Paris, vol. 63, pp. 199-230.

1977 The Inca Calendar, in: Native American Astronomy, Aveni A. F. (ed.), Texas University Press, Austin, pp. $219-263$.

1981 Inca Observations of the Solar and Lunar Passages Through Zenith and Anti-Zenith at Cuzco, [in] Archaeoastronomy in the Americas, edited by Ray A. Williamson, A Ballena Press/Center for Archaeoastronomy Cooperative Publication, Los Altos - College Park. pp. 319-342

1982a The sideral lunar calendar of the Inca, in: Archaeoastronomy in the New World, Aveni A. F. (ed.), Cambridge University Press, Cambridge-London-New York, pp. 59-107.

1982b Catachillay. The Role of the Pleiades and the Southern Cross and Centauri in the Calendar of the Incas, in: Ethnoastronomy and Archaeoastronomy in the American Tropics, A. F. Aveni y G. Urton (ed.) Annals of the New York Academy of Sciences, vol. 385, New York, pp. 203-229.

2008 The Astronomical Significance of Ritual Movements in the Calendar of Cuzco, in: J. E. Staller (ed.), Pre-Columbian Landscapes of Creation and Origin, Springer Science+Business Media, LLC 2008, pp. 249-267.

2010 El Calendario Inca. Tiempo y Espacio en la Organización Ritual del Cuzco; la Idea del Pasado, Fondo Editorial del Congreso del Perú / Fondo Editorial Pontifi cia Universidad Católica del Perú, Lima.

2014 Ceque System of Cuzco: A Yearly Calendar-Almanac in Space and Time, in: Handbook of Archaeoastronomy and Ethnoastronomy, Ruggles C.L.N. (ed.), Springer Science + Business Media New York, pp. 851-863.

\footnotetext{
Streszczenie: Coricancha (Qurikancha, Qorikancha) była najważniejszą świątynią w Cuzco, stolicy Imperium Inków Tawantinsuyu. Hiszpańscy Konkwistadorzy mieli okazję zobaczyć ją, i jej legendarne bogactwa, w listopadzie 1533 r., po wkroczeniu do Cuzco. Coricancha była miejscem kultu głównych świętych przedstawień inkaskiej religii, w tym figury Słońca, zwanej Punchao. Z tego wczesnego okresu pochodzą też wzmianki, niestety niezbyt precyzyjne, o specyficznej orientacji niektórych elementów świątyni, w celu uzyskania odblasku wschodzącego (lub zachodzącego) Słońca m.in. na wspomnianej figurze Słońca. Na tej podstawie źródłowej, oraz w oparciu o istniejące jeszcze fragmenty oryginalnej inkaskiej Coricancha, sformułowano szereg hipotez dotyczących możliwej astronomicznej funkcji tej świątyni. Szczególne znaczenia uzyskała hipoteza R.T. Zuidemy i A.F. Aveniego, zgodnie z którą obserwacje prowadzone w Coricancha stanowiły strukturalny szkielet specyficznego inkaskiego cyklu kalendarzowego, liczącego 328 dni. W niniejszym artykule przedstawiona jest krytyczna analiza tej hipotezy, na podstawie długoletnich badań i pomiarów przeprowadzonych w Coricancha przez autorów tekstu.
}

Słowa kluczowe: Inkowie, Coricancha, Punchao, orientacje astronomiczne, inkaski kalendarz, metrologia 